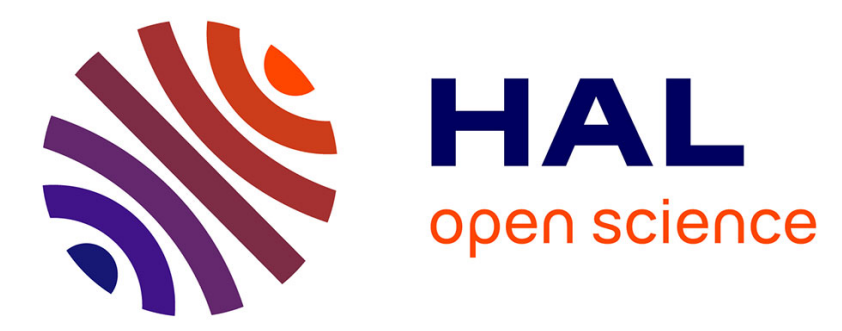

\title{
Crossing takeover premiums and mix of payment: An empirical test of contractual setting in M\&A transactions
}

Hubert de La Bruslerie

\section{- To cite this version:}

Hubert de La Bruslerie. Crossing takeover premiums and mix of payment: An empirical test of contractual setting in M\&A transactions. Journal of Banking and Finance, 2013, 37 (6), pp.21062123. 10.1016/j.jbankfin.2013.01.037 . halshs-00937550

\section{HAL Id: halshs-00937550 \\ https://shs.hal.science/halshs-00937550}

Submitted on 28 Jan 2014

HAL is a multi-disciplinary open access archive for the deposit and dissemination of scientific research documents, whether they are published or not. The documents may come from teaching and research institutions in France or abroad, or from public or private research centers.
L'archive ouverte pluridisciplinaire HAL, est destinée au dépôt et à la diffusion de documents scientifiques de niveau recherche, publiés ou non, émanant des établissements d'enseignement et de recherche français ou étrangers, des laboratoires publics ou privés. 


\title{
Crossing takeover premiums and mix of payment: An empirical test of contractual setting in M\&A transactions
}

\author{
Hubert de La Bruslerie ${ }^{1}$
}

\begin{abstract}
The analyses of the tender offer premiums and of the means of payment should not be performed separately. In the empirical literature, these two variables are often considered independently, although they may have an endogenous relationship in a contractual setting. Using a sample of European M\&As over the 2000-2010 decade, we show that these two variables are jointly set in a contractual empirical approach. The relationship between the percentage of cash and the offer premium is positive: higher premiums yield payments with more cash.

We highlight that the payment choice is not a continuum between full cash and full share payments. Two different regimes of payment in M\&A transactions are empirically characterized. We analyze the major determinants of M\&A terms when the offer premium and the means of payment are jointly set. The underlying rationale of an asymmetry of information and a risk-sharing calculus is found to be significant in the setting of the agreement.
\end{abstract}

Keywords: M\&A, takeover premium, means of payment, contract setting JEL: G32, G34

\footnotetext{
${ }^{1}$ Professor of Finance, DRM-Finance, University Paris-Dauphine, Place du Mal de Lattre 75116 PARIS (France) mail : hlb@dauphine.fr.

I thank E. de Bodt, F. Riva, D. Isakov, M. Hoesli, J. Martel and W. Megginson, for their suggestions and remarks. This paper was presented at finance seminars at the University of Fribourg and at HEC Geneva, at the 2011 AFFI Conference in Montpellier, at the 2011 CIG Conference in Montréal and at the 2011 Multinational Finance Society Conference in Roma. The financial support of the Fédération Bancaire Française Chair in Corporate Finance is greatly acknowledged.
} 


\title{
Crossing takeover premiums and mix of payment: An empirical test of contractual setting in M\&A transactions
}

\author{
Introduction
}

The empirical literature of mergers and acquisitions (M\&A) transactions largely examines the acquirer's point of view: Why decide to bid for a target? How to set the offered price? How to determine the means of payment? However the target shareholders may not agree the proposal and it may fails. Even through a public takeover bid, the investors, the board or the managers of the target may influence the bidder to review the terms of his offer. Finally, in most cases the deal will be successful but its terms may have changed since the inception of the process. The targets may influence the final terms of an M\&A deal (Faccio and Masulis, 2005). Successful takeovers are contractual agreements in which both parties find enough interest to agree on an offer. The two key variables defining this contract are the takeover premium and the offered means of payment. The basis of a contractual approach is that these key variables are jointly determined and agreed on as a package. We need to examine the way these terms will interfere. This paper will question how far that global contractual setting introduces a balance between the takeover offer premium and the means of payment.

Acquisition premium is a well-known measure, but the choice between means of payment is manifold: cash payment and share payment can be combined and an important number of European transactions are paid using hybrid cash-share schemes. The determinants of the means of payment have been identified: Contextual pressure or challenge for control may, for instance, explain the use of cash payment. Empirical regularities have also been identified for international cross border acquisitions, which are frequently paid in cash. The European context is an interesting empiric field to analyze M\&A transactions. The scope of share ownership is extensive, from dispersed ownership to controlled and family firms (Faccio and Lang, 2002). Using a sample of European firms, Faccio and Masulis (2005) focused on the univariate determinants of the means of payment. Martynova and Renneboog (2009) analyzed the financing decision and thus showed that the latter does not follow the same rationale as the payment decision. However the European context has not been used as an empirical field to complete these findings by testing the interdependency between the means of payment 
choice with the acquisition premium explicitely. We focus on European deals because very different schemes of payment are effectively used. However transactions develop in a homogenous regulatory context in the European Union countries; consequently the external and institutional determinants weigh less. The intrinsic characteristics of a deal will explain better the balance between the acquisition premium and the choice of means of payment specific to each transaction.

From an analytical point of view, a merger or acquisition is an economic project that generally poses some economic risks for the shareholders whether targets or acquirers. Both face an asymmetry of information which leads to the "double lemon" problem identified by Hansen (1987). This risk can be dealt with when setting the contract and using an appropriate choice of means of payment. Cash payment is a way for the seller to avoid risks by receiving liquidity, while shares payment is a way to make the seller bear some of the risks introduced by the project. The means of payment decision is a part of the contract, which is as important as the price itself because it is a way of sharing the expected risk (and profit) from the transaction. This should be particularly true in mixed payment schemes where the relative percentage between shares and cash payment is a parameter to set. In these contexts, the package of a mixed payment percentage and a takeover premium will define the contract, and both depend on the asymmetry of information.

The endogenous nature of the link between the takeover offer premium and the means of payment has not been extensively analyzed in empirical literature. Empirical studies have often analyzed either the takeover premiums or the means of payment, but rarely both (Eckbo, 2009). It has an important methodological consequence as a one-dimensional analysis of the premium or the means of payment is incomplete and so ignores their joint dependency. We will not pursue numerous empirical studies that look individually at premiums or means of payment because such approaches are incomplete and their results can be misleading. We need to use a methodology explaining jointly the setting of both the means of payment and the premium.

An empirical analysis is developed with regard to a sample of 528 European Union (EU) deals. Our contribution is to show a positive relationship between the percentage of cash and the offer premium: higher premiums yield payments with more cash. From a methodological point of view, we show that systems of simultaneous equations are better suited to the 
problem as they give different and better results compared to univariate analyses of either the premiums or the means of payment. Our findings support the view of M\&A deals as global and complex contractual equilibriums. We outline that the means of payment is not a continuous variable but refers to two different regimes of payment in M\&A transactions in which full cash or full share payments are "corner solutions." We find that the major determinants of M\&A terms when the premium and means of payment are jointly set include information asymmetry, the risk-sharing calculus between parties and the specific characteristics of the deal, such as cross border acquisitions, competition and same-sector transactions.

This paper is organized into three parts. Section 1 presents a review of the literature, and Section 2 presents the sample and variables. The empirical results are analyzed in Section 3. A conclusion follows.

\section{Literature Review}

\subsection{Takeover premium}

Takeover premiums have been extensively studied in the empirical corporate finance literature in relation to ownership structure or to the acquirer's or target's characteristics. The takeover premium level is often linked with the ownership structure of the target. For example, the high bargaining power of a large blockholder may force acquirers to offer higher bids (Stulz, 1988). The use of controlling devices, such as double voting rights, the separation of votes and cash flow rights, may enhance that positive relationship. The existence of shareholder agreements-commonly observed in Europe-is also viewed as an efficient mechanism of coordination inside the controlling group. It leads to higher firm valuation (Volpin, 2002; Belot, 2010), and it results in higher takeover premiums. Either the existence of an agreement between blockholders or the aggregate voting rights of the controlling party positively influences the takeover premiums for French firms (Belot, 2010). However, premiums are also the consequence of private benefits paid to the inside owners or to incumbent blockholders. The latter trade their benefits for a higher premium; otherwise, the incumbent shareholder will not accept losing his/her control and/or his/her private benefits. 
Bebchuk (1994), Burkard et al. (2000) and Burkart and Panunzi (2004) all support this view theoretically, and Moeller (2005) provides empirical support.

Deal characteristics are also important. For example, the contestability of the offer can lead to higher prices (Stulz et al., 1990; Song and Walking, 1993). The empirical literature documents a positive relationship between the target cumulative abnormal returns and the competitive nature of the bid.

When the target and the acquirer are from the same economic sector, merging may yield economies of scale and higher profitability. This motivation is measured by the similarity or identity of the SIC codes of the buyer and the seller. Synergy gains will explain higher bids by the bidder (Sundarsanam, 1996). The toehold is defined by the percentage of shares owned by the bidder and should yield a lower asymmetry of information. Betton and Eckbo (2000) showed that a toehold negatively influences the takeover premium.

On the target's side, size is a traditional control variable. A larger target firm size allows the premium to be spread over a larger investment. In line with Officer (2003), the relationship between size and the premium is expected to be negative. The financial leverage of the target is also important because it may signal a monitoring of the target firm by debtors. This is particularly true for blockholder-controlled companies or family firms. Debt leverage will limit private benefits, causing lower premiums. In contrast, higher debt leverage may be used as a power-enhancing tool for the controlling group and, consequently, may help appropriate private benefits. Stulz (1988) mentions that a target's controlling shareholder may force a bidder to pay a higher premium. Thus, the sign of the relationship is not defined.

The takeover process develops in the context of a double information asymmetry between the acquiring and target firms. Hansen (1987) was the first to mention the so-called "double lemons effect," in which each party has private information on his/her own value and has incomplete information on the nature of the assets he/she will receive. The bidder buys assets of uncertain value. Being risk averse, he/she is willing to pay less when facing an information risk. He/she may also want to share the valuation risk by paying with equity of the newly merged group. The target's shareholders will receive shares based on a new economic project, itself based on forecasted profits and synergies. They may also insure themselves by receiving cash and avoiding share payment. Asymmetries of information explain the risk-sharing 
attitudes of the buyer and the seller and, consequently, the choice of a mix of payments. Hansen (1987) measures the double asymmetry of information using the relative size of the target compared with the size of the bidder. The risk-sharing explanation is developed by Berkovitch and Narayanan (1990), who introduced the sharing of the synergy gains between the buyer and the target firm's shareholders into the analysis. The seller's appropriation of the synergy gains is linked to the difference in information between the two parties. Chang and Mais (1998) expanded the idea that an exchange of information can help to solve the problem of double information asymmetry. They introduced a prior holding in the target's capital (a "toehold") as a means to reduce the buyer's asymmetry of information. In such a situation, the buyer has better inside knowledge of the target, especially if he/she holds a large portion of capital (Goldman and Qian, 2004). Cheng et al. (2008) used a sample of US firms to compare asymmetries of information, bid premiums and the means of payment. They show that the means of payment and bid premiums are interdependent, with the means of payment heavily conditioning the price paid in the deal for a given asymmetry of information between the two parties. This suggests that the two terms are linked from a contract design perspective.

\subsection{Means of payment}

The literature devoted to the means of payment follows another strand. A payment with shares has no consequence on the cash situation of the firm because the acquirer issues new shares. However, it may have consequence in terms of the following: (i) a signal to the firm's shareholders and (ii) the wealth situation of the final shareholders because of dilution.

In a M\&A decision, a bidder faces a choice between using cash and stocks as deal payment consideration. This alternative choice has conflicting effects and follows different motivations. A first rationale follows from the idea that the financing decision is separated from the investment decision. The M\&A project is first selected, and then the acquirer considers ways to optimally finance the possible deal. The constraints here are the limits on the financial leverage or the shareholder control structure of the bidder. Generally, bidders have limited cash and liquid assets; thus, cash offers require debt or equity financing. The pecking order theory says that acquirers will first choose internal funds, which are available either as cash holding or as internally generated cash flow. Initiators with cash available will prefer a cash payment (Martin, 1996). Partial or full payment in shares may express the existence of financial constraints (Myers and Majluf, 1984). However, equity financed 
transactions make it difficult to retain control when shareholding is concentrated. As Faccio and Lang (2002) noted, this situation occurs frequently in the EU. As a consequence, a bidder implicitly faces a choice of debt or equity financing, which involves a trade-off with corporate control concerns. Faccio and Masulis (2005) explain mixed payments in takeovers by the structure of control and by the debt level of the acquiring firms. Their empirical tests on European mergers and acquisitions support the idea of a preference for a cash payment when there is a large shareholder with $20 \%$ to $60 \%$ of the capital of the buyer. The bidder's M\&A payment decision is strongly influenced by his/her debt capacity and existing leverage. It can also be strongly influenced by entrenched managers or by the blockholder's desire to maintain the existing corporate governance structure.

Payments in cash, either full-cash or mixed cash payments, need to be financed. The existing literature analyzes the means of payment without questioning the source of funding the M\&A transaction at the acquirer's level. The acquirer may issue and sell new equity stock, issue debt, or use the firm's cash holding. Martynova and Renneboog (2009) analyze the financing decision behind the choice of the means of payment in M\&A transactions. Externally financed M\&A transactions are funded $30 \%$ by equity and $70 \%$ by debt. In a sample of European deals, they show that the financing decision and the choice of the means of payment are driven by distinct determinants and are not interdependent. However, they also show significant evidence of an indirect and reverse influence of the means of payment on the internal/external financing choice. There is also an influence of the bidder's choice on whether to share the risk of the transaction with the target's shareholders and/or to buy out these shareholders. In such a situation, equity payments and equity financing are preferred.

The means of payment choice is also sensitive to the genuine context of the deal. Strategic competition between bidders is the first reason given to prefer cash. Fishman (1989) analyzes the strategic role of the means of payment in public takeovers and finds that pure cash offers are dissuasive against competitors and signal high quality target firms. Fishman relates the payment by cash to the future profitability of the target as expected by the competing bidders. However, his model leads to cash-only or share-only payments. Cornu and Isakov (2000) develop a model in the context of a competitive offer between two acquiring firms. To disclose information about his strategy, the first bidder can use a signal through the announcement of a pure cash or a pure share payment. However, since the 1990s, the large majority of mergers and acquisitions are non-hostile, and the means of payment are 
diversified (Shleifer and Vishny, 2003). The characteristics of the payment scheme have to be analyzed in the context of the known success of the takeover.

The portion of capital the bidder wants to receive (beyond gaining control) is an adjustment variable. That fraction reveals private information about the buyer's real value. If the means of payment discloses private signals to other parties, it will in return also influence the process of negotiation. Hansen's (1987) model explains the probability of paying in cash or in shares but does not focus on mixed payment schemes. A double asymmetry of information may explain the risk-sharing choices and the payment by issuing shares. Eckbo, Giammarino and Heinkel (1990) refer explicitly to the idea of an optimal mixed cash-shares payment. They were the first to highlight that the weighting between these two means of payment will reveal to other parties the respective quality of competitive buyers. Martin (1996) links the cash payment with private information: an acquirer with good growth opportunities will prefer a shares payment.

The empirical literature on the means of payment identifies a different rationale to explain the cash or equity choice (Carleton et al., 1983). Cash acquisitions are found to have better performance post-merger (Linn et al., 2001). The literature on mixed cash-equity payments is relatively recent, even though mixed payment schemes have become increasingly important in mergers and acquisitions, particularly when considering offers for large firms (Betton et al., 2008). Goergen and Renneboog (2004) analyze public takeover bids in Europe during the 1990s. Looking at a sample of 156 offers, they found 93 were pure cash, 37 were pure shares and 18 were mixed payment deals. Among the latter, the portion of cash accounted for $45.9 \%$ of the total payment. Faccio and Masulis (2005) considered a larger sample of 3,667 mergers or acquisitions of European firms at the end of the 1990s. The number of mixed payment operations is only $11.3 \%$ (with an average proportion of $57 \%$ in cash and $43 \%$ in shares). The size of a mixed payment takeover bid was five times (1.1 billion USD) greater than the size of a standard pure cash offer (209 million USD). Mixed payment schemes represent a far greater proportion of transactions as the value of transactions rises. ${ }^{2}$ However, this discrepancy is largely explained by cross-border transactions, in which a large number of small deals are paid in cash. In recent years, the number of mixed payment takeovers has increased.

\footnotetext{
${ }^{2}$ The high number of all-cash takeovers in their sample is partly explained by the number of cross-border takeovers with US bidding firms, which are generally full payment in cash.
} 
Martynova and Renneboog (2006) consider 1,721 European takeovers between 1993 and 2001 and discover that 54\% were all-cash, 25\% were mixed and 20\% were all-equity transactions. On average, a mixed payments scheme is comprised of $47 \%$ in stocks and $53 \%$ in cash. Ben-Amar and Andre (2009) examined 293 Canadian mergers and acquisitions from 1998-2002. The sample composition was 58\% cash-only, $19 \%$ stocks-only and $22 \%$ mixed payments. However, the latter represented $32.3 \%$ of the total value of the transaction, pointing out that mixed payment takeovers occur more frequently in higher value transactions. For mixed payment takeovers, the average percentage of cash was $49 \%$ but with a standard deviation of $50 \%$, corresponding to huge differences within payment schemes.

Cross-border M\&A transactions are more likely to be paid in cash. This traditional feature is documented by Chevalier and Redor (2007), who show that geographical distance is a good proxy for cultural distance. Geographical distance is also a source of asymmetries of information for transactions. This explains why cross-border acquisitions are more often paid in cash. The dependent variable used by Chevalier and Redor is the percentage paid in cash for US acquiring firms and includes mixed payments. The target shareholders will prefer cash because shares from a foreign firm may not be easily traded. The quality of the assets of a distant company is more difficult to assess. That information asymmetry develops with distance is shown by Chevalier and Redor (2010). Conversely, the tax system will generally favor equity payments. In European tax systems, payment by cash is considered a sale, and the shareholder who exhibits effective gains will thus be subject to income tax. Share payments are an exchange of assets and are not considered taxable effective gains; thus, the target's shareholders can defer later tax liabilities by accepting stock as payment.

\subsection{The contractual nature of M\&A transactions}

The chosen means of payment may also reveal the specific characteristics of the transaction. An M\&A transaction is an economic project and a contractual agreement with a seller. The target's shareholders are not forced to sell (except in buyout transactions). The risk of asymmetry of information is (partially) solved in such a contractual setting by the level of the premium and by the choice of means of payment. The choices are not univocal but occur in a process conveying private information from one party to the other. La Bruslerie (2012) analyses the interaction of the relationship between offer premiums and the means of payment. If the risk on the target's assets is important and if the acquirer's shareholders are 
risk averse, the latter may prefer payment in shares. However, if the potential profits after the acquisition are large, the acquirer's shareholder will offer payment in cash to keep more of the resulting profit (Shleifer and Vishny, 2003). The equilibrium between risk and return explains the choice between means of payment, and a trade-off will develop with the acquisition premium. If a buyer is insured against future bad news through a payment by shares, he/she can offer a better price. This equilibrium may give "corner solutions," either full cash or full share payments. However, it may also lead to mixed payments, in which the percentage paid in cash is a relevant measure of information asymmetry. The same calculus follows from an inverse point of view by the targets' shareholders. They are exposed to an information risk on the future gains in synergy and on the expected profit of the newly merged company.

Theoretically, from the buyer's point of view, (i) correlated activities and economic risk between the target and the acquiring firms will result in a larger payment with cash, and (ii) a trade-off develops between the percentage in cash and the premium paid in the acquisition (La Bruslerie, 2012). For the acquirer, the cash payment portion increases with prospective profit due to synergy gains, as in Shleifer and Vishny (2003). The seller will accept a negative tradeoff between a higher (lower) cash payment and a lower (higher) transaction price and, thus, a lower/higher portion of the expected acquisition gain. A mixed payment will develop only between "corner solutions" of full cash or full share payments, in which the expected profit from the acquisition is between two limits.

The regulatory environment may also play a significant role in the contractual setting. Some countries have developed investor protection regulations that facilitate M\&A transactions. In the European Union, regulation is effective and gives strong protection to shareholders, including enforcing an equal treatment principle between shareholders. The EU's $13^{\text {th }}$ directive was formally adopted in 2000 and implemented in European countries, although with some local differences. Any takeover bid or private acquisition should be analyzed by the EU administration and comply with anti-monopoly rules. European financial regulation is set at the global level and tries to set up "a unique global financial market." The accounting policy in Europe should also comply with common rules. As an example, the introduction of the new common IFRS rules was enforced in 2005. Legal rules and procedures are taken at the country level but must conform to the EU "directives." Their selective introduction in each domestic law system may also explain differences. La Porta, Lopez-de-Silanes, Shleifer, and Vishny (1998) highlight the importance of the legal system. However, the legal code 
indicators-flagging Scandinavian, French, Anglo-Saxon or German origins-are found to be insignificant by Faccio and Masulis (2005). We will therefore limit the influence of the regulatory environment by looking only at M\&A transactions targeted at firms located in the seven major European countries (UK, France, Italy, Germany, Spain, Italy and Belgium). We will disregard the recent entries into the European Union, such as Eastern European countries, or tax-haven countries (Luxembourg). The sample is then homogeneous with regard to regulation.

\section{Data and variables}

\subsection{Data}

The sample of European takeovers has been built from the Thomson One Banker database. The period is limited to transactions between January 1, 2000, and May 1, 2010. A filter is used to focus on meaningful operations and a minimum transaction value of 50 million USD is required. Only completed deals are considered. ${ }^{3}$ Target companies are limited to firms belonging to the seven major EU countries: France, Germany, United Kingdom, Spain, Belgium, Netherlands, and Italy. We select deals in which the types of targeted assets by the acquirer are stock or equivalent stocks (i.e., assets giving rights to stocks). The means of payment examined are only cash or stock.

We excluded offers coming from less-developed countries, thus restricting our sample to North American, European, and Japanese buyers. If the acquirer proposes stocks as a valuable means of payment, it requests that a large transparent market exists for the bidder's stock to be accepted. This is why we restricted both targets and acquirers to be public firms. We thus narrowed the sample to 528 transactions. We checked the mode of payment through the data. Many deals are qualified as "cash only" or "stock only" in the database. Mixed payment transactions were also screened. Those qualified as "hybrid" show a payment scheme with a percentage of cash and stock. We only consider "pure" mixed payment with a percentage of cash and a percentage of stock summing up to one. Some deals are qualified as "unknown."

\footnotetext{
${ }^{3}$ The question of a bias in selecting our sample does not arise. We only consider contracted deals, in which an agreement is found between the acquirer and the target. By definition, not completed deals are ones in which an agreement has not been reached. The analysis of their key variables and provisions is not relevant in a contract setting approach in which an agreement reveals an economic equilibrium between the parties.
} 
By looking at each operation syllabus, we can allocate many of them to mixed payment schemes. Deals with earn-out payment considerations are excluded because of this uncertainty. Some transactions may involve payment in debt (particularly in the UK). This possibility is proposed alternatively with a cash payment. When analyzing deals with a debt payment, they generally appear to be equivalent to cash payment. Thus "cash payments" in the paper are defined as in Faccio and Masulis (2005) and include cash, non-contingent liabilities and newly issued notes. We incorporate in the sample a lot of hybrid cash/debt/stock payments and recalculate the percentage of cash and shares summing up to one. $^{4}$

The Faccio and Masulis (2005) sample considered deals from European bidders directed to any country in the world. It gives a large weight to UK firm deals (65\% of the sample). We look at M\&A targeted at European firms from other major developed countries. Similarly to Faccio and Masulis (2005), our sample is mainly intra-EU: in their sample, $77 \%$ of the bids come from European countries, while $79 \%$ do in our sample.

Some deals were not documented without a price, or they were initiated by Russian entities or were squeeze-out transactions ( 2 deals). ${ }^{5}$ They were not considered. Thus, we were left with 504 transactions. The analysis of the sample leads us to identify some transactions that are buyback programs launched by the company's board. Here the target's shares are the company's stocks or a subsidiary's. In these situations we do not have independent targets and acquirers; thus, buybacks were deleted (72 transactions). The remaining core of our sample is 432 transactions, of which 294 are full cash payment, 62 are mixed cash-share (called "hybrid") and 76 are full share payments. The global value of these deals is 898 billion USD. Some large acquisitions explain this amount: the largest transaction is the Beecham/Glaxo acquisition, which has a transaction value of 76 billion USD. The smallest operation has a transaction value of 50.2 million USD.

\footnotetext{
${ }^{4}$.Our sample includes a total of 12 mix-and-match optional payments. They are typically UK deals where a supplementary loan note consideration is offered (Goergen and Frecknall-Hughes, 2007). These loans are floating rate notes with a benchmark rate based on the LIBOR and were proposed because of tax benefits to British residents. These mix-and-match payments have not been used since 2002. We assumed that a loan payment is equivalent to a cash payment. We consider the mix-and-match deals from the initiator's point of view and look at the real cash percentage paid at the end of the deal.

${ }^{5}$ We also eliminate buyout deals from the analysis. They are not transactions between shareholders of two different and independent firms. They are decisions made by managers on behalf of the controlling shareholders to buy the shares of the firm and do not involve another party.
} 


\subsection{Descriptive statistics}

When considering the three sub samples of full cash, full share and hybrid (i.e., mixed cashshare) payments, we note differences in the average deal size (see Table 1, panel A). As in Faccio and Masulis (2005), we find that cash deals are the most numerous but also have a relatively small size. Hybrid transactions are three times larger than all-cash paid deals (five times in Faccio and Masulis' sample). Full share payments are important deals. The cumulative values of the deals paid fully either in cash or in stock are equivalent (approximately $40 \%$ of the grand total each). The mixed payment transactions are not negligible; they represent a cumulative value of 211 billion USD and 24\% of the total sample. A test of difference in average size shows that shares and hybrid transactions are not different $(\mathrm{p}=0.34)$, but the differences in size between full cash and hybrid transactions, on the one hand, and full cash and full share transactions, on the other hand, are significant at the 5\% level (both $\mathrm{p}=0.03$ ).

\section{INSERT TABLE 1}

An important number of deals are private transactions. Direct negotiation between the two parties converged, and a block sale occurred. A total of 66 private transactions are identified, often linked to going public to private operations. All these private acquisition are "cash only" deals.

The sample of targets firms shows a large number of deals targeted at British firms (43\%). Martynova and Renneboog (2009) have noticed the same dominance of British firms in their sample. The transactions initiated by acquirers located in the EU represent $79 \%$ of the sample (i.e., 340 deals). Cross border deals ( $21 \%$ of the total) will refer to non-EU acquirers. ${ }^{6}$ Table 1 analyzes the origin country of the target by means of payment. We introduce a distinction between cross border acquirers coming from the USA and acquirers coming from the rest of the world. We see that pure intra-country deals are paid fully in cash 6 times out of 10 and fully in shares 2 times out of 10. This changes when a non-US acquirer enters into a cross border acquisition in Europe: he/she will 9 times out of 10 pay fully in cash. However, looking at initiators coming from other EU countries or from the USA, they have similar

\footnotetext{
${ }^{6}$ In the perimeter of the seven European countries, we considered in selecting the location of target firms.
} 
proportions of mean of payment. For instance, we cannot say that US acquirers will systematically pay in cash. They use full cash payment only 3 times out of 4 .

We analyze the industry sectors of the acquirer and the target firm using the Thomson Financial codes. A total of 219 mergers (51\%) are between firms in the same industry.

A deal is aimed at buying a large block of stocks, generally giving the initiator a majority of the equity capital. However, the shares purchased at the end of the operation should take into account the shares previously owned by the bidder. A toehold may explain why the percentage of shares sought is lower, even if it gives a controlling position at the end of the deal. The percentage of shares owned after the transaction is calculated by adding shares and shares previously held. On average, the percentage of acquired shares is $58 \%$, the percentage sought in the deal is $61 \%$, and the percentage owned after the transaction is $72 \%$ of the capital. It means that significant toeholds exist, representing on average $14 \%$ of the capital. This is explained by the subsidiary feature of many target firms. A total of 101 targets are subsidiaries (19\% of the total sample). Among the subsidiary targets sub-sample, the toehold percentage averages $45.6 \%$ (median $54.6 \%$ ) of the capital. The non-subsidiary firms have an average toehold of only $8.5 \%$.

Cash payments exhibit a lower acquired percentage and a lower owned percentage after the deal. This is explained mainly by private block acquisition, in which the average purchased block represents $22 \%$ of the capital. However, in that situation, the toehold is more important and shows a significant previous investment in the target's capital (approximately 23\%). The cash payment in a typical public takeover is targeted at larger acquisition of capital (an average of $65 \%$ ). As a result, we see that the aim of M\&A transactions is control because the final owned percentage is largely approximately 80 to $90 \%$ of the capital of the target firm. We separate cash deals into those following a private acquisition mechanism and those following a public takeover bid. Private deals also seem to follow a rationale of a control building process. The acquirer of a block takes advantage of an opportunity given by a seller even if the size of the block in itself does not give an immediate control of the target. Many blocks are small block acquisitions (with median private acquisition of $16 \%$ of the target's capital). In the case of private deals, the acquired block together with prior ownership results in a final equity stake of $45 \%$ of the capital, which implies a controlling position. In European 
M\&A transactions, on average, a stake of $56.08 \%$ of capital is acquired in full cash deals, compared with $85.66 \%$ in hybrid payment schemes and $77.74 \%$ in full share payments. The differences in percentages of capital acquired or owned are significant when comparing full cash payments and other payment schemes (at the $1 \%$ confidence level). ${ }^{7}$

Looking at mixed hybrid payments, the average percentage paid in cash is $48 \%$. The distribution of the percentage of cash is large. For instance, the lower quartile of the mixed payment deals have a cash payment part that is below 30\% in the payment mix; the upper quartile of mixed payment deals shows a percentage paid in cash above $66 \%$.

The offer premiums are the other term of the transaction. According to the means of payment, they stand between 17 and $28 \%$ of the target's share price one day before announcement. Average premiums are similar when comparing full cash and hybrid payment transactions. A t-test rejects the idea of different premiums according to hybrid or full cash payments. Share payment premiums seem to follow another rationale by staying below the others. However, this result is weak because it is significant only at the $10 \%$ level (see Table 2).

\section{INSERT TABLE 2}

\subsection{Variables}

The variables used in the regression analyses are described in the appendix. Most of them are taken from the Thomson One Banker database.

The financial condition of the acquirer is a first explanation of the choice of means of payment and of the price paid. Cash holding/accessibility of the acquirer is identified with ACQ_PC_CASH and ACQ_PC_EBITDA. These two variables compare the cash holding and the EBITDA as a measure of internally generated cash to the value of the transaction. Large cash availability at the acquirer's level will favor cash payment. Raising debt is also a substitute for internal cash payment: it depends on the debt capacity of the acquiring firm as measured by the acquirer's financial leverage, ACQ_LEV. The idea here is simply that highly leveraged firms are more likely to choose equity financing. These variables are drawn from the acquirer's financial report at the end of the year prior to the deal. Target leverage is also

\footnotetext{
${ }^{7}$ However, the means are not different when considering hybrid and full share payments.
} 
an element that can influence the acquirer's capacity to finance the deal. In a successful merger, a low leveraged subsidiary with a good debt capacity will help the initiator to finance the deal using debt and cash. TARG_LEV is a variable that measures the target's financial leverage. It is set as the ratio of the equity value of the target (valued using the offer price) divided by the total enterprise value of the target (with equity also taken at the offer price) minus one. These leverages are market valued. ${ }^{8}$ The cash situation of the target is also an element of interest because a large cash balance allows the buyer to partially finance an acquisition with the target's own cash. We use the variable TARG_PC_CASH. A large cashflow from the target is also an element that helps to repay debt issued by the initiator when implementing the transaction. For that purpose, we consider its operating margin ratio, EBIT_ROA.

The target Tobin's $\mathrm{Q}$ may be proxied by the ratio of its equity valued at the offer price compared with the book value of equity at the last financial report; it is named TARG_Q. The Q values measure the growth opportunities of the buyer and of the seller. It is also a proxy of possible market overvaluation of the acquirer's stock value. The PERC_ACQ_SH_ISSUED variable is used as a proxy for assessing the control situation of the acquirer. As in Faccio and Masulis (2005), this variable is set using a 20\% control threshold. Another dummy takes into account the subsidiary feature of the target (DUM_SUBSIDIARY).

The competitive nature of the takeover has been identified in the literature as a strong argument for cash payments. The idea is simple: cash is a signal of the will of the bidder to acquire a target and deter competition by other potential bidders (Fishman, 1989; Berkovitch and Narayanan, 1990; Cornu and Isakov, 2000). The competitive context can be measured by a dummy variable (DUM_CHALLGD_DEAL). A dummy for the friendly attitude of the target is also used (FRIEN_ATTITUD).

We introduce a variable for toehold (which is set comparing the percentage of shares owned after the transaction and the percentage acquired through the transaction). The variable TOEHOLD gives the percentage of shares previously owned. A dummy DUM_TOE is also used when a toehold exists. Toeholds may limit asymmetry of information.

\footnotetext{
${ }^{8}$ We also considered book leverage, which gave similar empirical results.
} 
The double asymmetry of information is measured using the relative size of the target compared with the size of the bidder. A first measure of asymmetry following Hansen (1987) is the relative values of target net asset divided by the acquirer net asset using book data (ASYMMETRY\#1). The relative amount at risk is also measured by introducing another variable to gauge the situation of asymmetry: we compare the transaction value with the acquirer net asset value (ASYMMETRY\#2). This measure considers the total economic resources involved in a takeover where the motivation is control on assets. The transaction value is the economic amount at risk from the acquirer's point of view. Furthermore, this variable is not influenced by the debt policy of the acquirer ${ }^{9}$.

The first deal characteristic is the percentage offer premium (OFFER_PREMIUM_4W) which divides the offer price by the stock value available in the market 4 weeks before the announcement of the transaction. ${ }^{10}$ Another important feature is the means of payment which is measured either in a dummy form (DUM_CASH, DUM_SH, DUM_HYBRID) or in percentage (PERC_CASH). We introduce ex ante features of the deal: PERC_SOUGHT is the percentage of capital initially sought by the initiator. It may be used by comparing it with the ex post stake of capital effectively acquired, PERC_SH_ACQUD. The DISEQ variable measures the imbalance from the acquirer's point of view between the stakes of capital as wanted ex ante and effectively received ex post. It is measured by subtracting the later variable to the former. The institutional context of the deal is acknowledged with a dummy for domestic acquisitions (DOMESTIC_ACQ) and a dummy for intra EU transactions (DUM_EU_ZONE) flagging initiators that are incorporated in the EU. The TRANS_VAL value is in absolute size; it is used to see if the absolute amount of the transaction influences its outcome. The economic context of the deal and the purpose of business diversification is followed with a dummy SAME_SECTOR variable.

\footnotetext{
${ }^{9}$ A similar asymmetry variable can be derived using market values instead of book values. However this data is not available for each target in the sample.

${ }^{10}$.Premiums are calculated using a four-week time lag between the offer price and the prior stock price. This takes into account a possible stock price run up before the transaction. Martynova and Renenboog (2011) identify such a run-up starting 40 to 60 business days before the public announcement. Looking at our sample, the average premium decreases while the time lag shortens: it is $30.3 \%$ four weeks before, $27.7 \%$ one-week before and $25.2 \%$ one-day before the announcement. This is in line with the hypothesis of insider trading and the diffusion of private information. We followed the Martynova and Reneboog (2011) approach and use a four weeks event window. We checked our results and obtained similar results when using a shorter one-week lag for offer premiums.
} 
The asymmetry, the offer premium, the leverage, and the Tobin's Q variables are winsorized at the $1 \%$ and $99 \%$ percentiles. We checked the correlation between the variables. Cross correlations between ASYMMETRY\#1 and TARG_LEV (0.38), ASYMMETRY\#1 and TRANS_VAL (0.32), ASYMMETRY\#2 and TRANS_VAL(0.40), ACQ_PC_CASH and ACQ_PC_EBITDA(0.69), PERC_SOUGHT and TOEHOLD(-0,33), ACQ_PC_CASH and TARG_LEV(-0.50), are important (above 0.30). Thus, we disregard the redundant explaining variables. The two variables ASYMMETRY\#1 and ASYMMETRY\#2 are highly correlated $(0.43)$.

The descriptive statistics of the variable are presented in Table 3. The proxy of asymmetry of information shows that the bidder is relatively better informed than the target. The Tobin's Q value of the target and the acquirer are similar (3.6 vs. 3.3). An average toehold of $47 \% \%$ for those 159 firms holding shares (30\% of the sample) is evidenced. The acquirer seeks a percentage of $61 \%$ of the target's capital. He/she gets only $58 \%$, and as a consequence, we see a 3\% disequilibrium. Due to previous toeholds, the acquirer ends the transaction with a cumulative stake of $73 \%$. The average offer premium is $30.3 \%$.

INSERT TABLE 3

\section{Empirical tests}

\subsection{Methodology and hypotheses}

According to Faccio and Masulis (2005),

« Since we expect both bidder and target preferences to affect the offer price and its form of consideration, we would ideally like to simultaneously estimate equations capturing the two parties' preferences. However, identification requires information about a target's stand-alone value relative to its purchase price (takeover premium) as well as the form of payment. Access to information about a target's stand-alone value is unavailable, given that most of these firms are privately held. This precludes estimating the alternative purchase prices conditional on form of payment. As a consequence, we have chosen to estimate a reduced form equation that includes both parties' preferences as explanatory variables. » We do not follow this approach, which in the end collapses to a univariate regression of the means 
of payment. While recognizing that the parties have two dimensional preferences, Faccio and Masulis argue that the private status of the target firms and the poor availability of data are the reasons for not implementing a two dimensional analysis. This analysis seems rather casual. Our sample covers both public acquirers and targets. However, data availability for the above is not the first reason to develop a system of simultaneous equations. The main reason is that premium and means of payment have an endogenous relationship, thus we are dissatisfied with univariate modeling. We will empirically check if multidimensional methodology does better by comparing univariate estimates with simultaneous equation estimates.

The hypothesis to test is that mix of payment and premiums are jointly set. We intend to set up a simultaneous equations model explaining their values.. The same methodology was used by Officer (2003) to take into account the endogeneity between the premium and the existence of the termination fee paid to the bidder. In a first step, to build up the model, we analyze separately the determinants of the payment decision and those of the premium among a list of variables.

The variables conditioning the setting of the contract are mentioned in Table 4. We considered a limited sub-sample of variables after taking into account colinearities. The expected relationship of each one versus either the percentage of cash (covering the three situations of full share/mixed/full cash payments) or the premium paid is also mentioned. We introduce a distinction between the three main explicative theories: (i) the financing decision explanation, (ii) the asymmetry of information and contractual setting approach, and (iii) the conditioning by the environmental characteristics of the deal.

\section{INSERT TABLE 4}

The percentage of cash in a financial constraint approach is supposed to be positively linked with the acquirer's cash holding and Ebitda, and with the target's operating margin. The flow of funds variables are the ones considered by the debt and credit markets. The percentage paid in cash should be negatively linked with leverage, with the absolute size of the transaction and the percentage of acquired shares. The overvaluation hypothesis introduces a negative relationship with cash features when the acquirer wants to time the stock market to finance 
the transaction. The asymmetry of information introduces a risk sharing preference. The existence of a toehold will favor cash in the means of payment scheme. The toehold is a way to access better information and to reduce the asymmetry problem. The bidder will be willing to pay more in cash when he/she is less exposed to information asymmetry and enjoys improved information. The existence of a toehold or the subsidiary status of a target is viewed as a device to reduce the asymmetry, and the acquirer does not need to issue shares for risksharing purposes. Conversely, the absence of economic diversification due to same industry M\&As will favor shares in the payment scheme. The premium is linked in the contractual setting with the means of payment. At equilibrium, for hybrid payments, the acquirer may be willing to pay a slightly higher premium (i.e., to abandon a higher part of the M\&A net value to the seller) if he/she can seize a larger part of the future profits and avoid dilution by paying more with cash. Conversely, the target's shareholders will capture the actual value of future gains by accepting more immediate cash. The environmental features are known: cross border and challenged deals are more largely paid in cash. Governance pressure may also explain lower share payments if the number of new shares issued following the acquisition is high. If the initiator's shareholders fear dilution or loss of control, they will be prone to pay more in cash if there is an important blockholder in the target's capital who may become an important blockholder in the newly merged company. This control feature is not explicitly addressed in the list of regressors because of the colinearity between the information asymmetry variables and PERC_ACQ_SH_ISSU (correlation coefficient of 0.47).

Looking at the offer premium relationships, liquid and profitable firms can pay more. The same may be true if they have a large Tobin's Q to time the market and issue highly priced shares. The asymmetry of the information approach says that the asymmetry of information is a risk that is balanced by lower prices and premiums. Targets that are subsidiaries, or where toehold stakes held by the acquirer exist, are more transparent to the buyer and can command a higher price. The same is true if the opportunity growths of the target are large. The percentage of cash has a trade-off relationship with the premium paid. The context of the deal will also influence the price with an increase of cash payments if it is challenged or if it is a cross border deal. Similarly, for large size targets, the bidder will pay more in shares.

The DISEQ variable takes into account the possibility that the final terms are not equilibrium terms from the buyer's point of view. It is the difference between the percentage of shares sought in the deal and the percentage effectively bought. A positive discrepancy means that 
the acquirer should have paid more to obtain a higher stake of capital. Thus, we expect a negative sign.

The acquirer's Q ratio is a double face variable: it can signal an overvalued share value and a possibility to time the market by the bidder's managers (Betton et al., 2008). However, it may also signal the positive economic qualities of the firm (Martin, 1996). Former shareholders may not want to share growth opportunities with new blockholders. To avoid the dilution of the former shareholders, the payment in shares to new shareholders is voluntarily limited. Financial constraints or limitation may explain equity payment and financing: this will occur when the percentage of shares acquired or the size of the deal is large.

\subsection{Determinants of the payment decision}

The means of payment decision may be analyzed as a continuum between 0 and $100 \%$ cash payment. This approach views the determinants as playing a continuous role to explain the cash percentage. Traditionally a linear model will imply that a significant given determinant explains at the same time a full cash, a full equity or a mixed payment. The hypothesis of a unique set of determinants over the scope of cash percentage payments is very strong and questionable. The alternative hypothesis is that there are possibly three different regimes of means of payment, each one explaining either the full-cash, the full equity, or the mixed cashequity payments. The idea of three regimes is based on the hypothesis that the full equity and the full cash payments are "corner solutions" for a rational investor (La Bruslerie, 2012). Even a methodology using Tobit regression, as the one implemented by Faccio and Masulis (2005), relies on the hypothesis of a unique set of determinants. A Tobit model does not allow for the possibility of different rationales in choosing the means of payment.

A Probit analysis to identify the variable influencing the decision of each means of payment against the other two is not sound. We cannot conclude that, when choosing a hybrid payment and rejecting full cash or full share payments, the acquirer is indifferent between the last two. $^{11}$

\footnotetext{
${ }^{11}$ In an explanatory attempt, we have analyzed pure alternative choices using a Probit analysis of a means of payment against another one. With three different means of payment, this yields three Probit analyses. In each case it is shown that a larger offer premium increases the possibility of a hybrid or a cash payment.
} 
The acquirer's Q is positively linked with share payment, which is in line with the stock overvaluation explanation. It does not support the idea of privately known growth opportunities at the acquirer's level, which would lead him to prefer cash payments (Martin, 1996). The target's Q ratio is significant and negatively linked with cash payment. Good opportunity growths at the target's level may favor full or partial payment with shares. This is in line with what was expected because the acquirer is facing an information risk about the opportunity growth of the target. A large part of the latter's value exceeds the assets accounted for in the balance sheet. Therefore, a higher exposure to risky information on the off-balance sheet value may push the acquirer to cover that risk using share payment.

We used an ordered Logit model where the dependent variable equals two in full cash, one in hybrid, and zero in full equity payment considerations (as in Faccio and Masulis, 2005). We also use a multinomial Logit test of the three cases in the spirit of Martynova and Renneboog (2009).

An ordered Logit model is performed over a set of 12 explaining variables (Model 1) and a restricted set of six variables (Model 2). It gives poor results. The size of the target increases the probability to use hybrid and full cash payments, which is controversial. We obtain any relationship with the premium and a negative relationship with the asymmetry of information proxy is evidenced in the Model (2). However share payment is more frequent in domestic M\&A transactions, which matches the fact that cross border acquisitions are paid with cash. In line with the contractual analysis, same sector deals are more frequently paid using shares.

\section{INSERT TABLE 5}

Nevertheless, the ordered Logit model introduces a unique set of parameter values and uses cuts to create three classes. A restricted multinomial Logit is concurrently run and offers the possibility to yield different sets of explaining variables focusing on alternate means of payment. It tests jointly the difference between all-cash and hybrid payments and the difference between all-cash and all-share payments. Two sets of determinants are considered a larger one (Model 3, 12 variables) and a restricted one (Model 4, six variables). Any of the variables are significant in the first case, expect the challenged status which strongly yields all-cash payment. With regard to the full cash/full share payment alternative, the probability 
of choosing the full cash payment increases with the offer premium and the acquirer $\mathrm{Q}$ ratio. The probability of choosing the all-share payment increases with the information asymmetry and the target $\mathrm{Q}$ ratio (see Table 5). This relationship was expected in the contractual setting presented in the Table 4. Challenged deals also significantly lead to full share payments. This result illustrates that full cash and full share are opposite corner solutions (Carleton et al., 1983). At the same time, the variables explaining the choice between cash and hybrid payments seem to be different ones because none of the previous variables are significant. This result supports the idea that hybrid payment choice follows a different rationale and is explained by other variables. The overall regime of payment explanation covers these two different rationales for means of payment.

\subsubsection{Modeling alternate cash/share payments}

We used a restricted list of 8 independent variables to explain the alternate full cash/full share payments (see Table 6). The asymmetry variable that fits the best is ASYMMETRY\#2. Both the Probit and the OLS estimates confirm the previous results. The cash payment probability is negatively linked with the absolute transaction value, the same sector dummy, the domestic acquisition dummy and the asymmetry of information. It is positively explained by the acquirer's relative cash flow and the offer premium. This is consistent with the cash availability explanation and the financial limitation theory (Martin, 1996).

The percentage of share payment increases when the target and the acquirer are in the same sector. This is consistent with the risk diversification analysis: when the merger does not develop in a context of economics diversification, the buyer is more prone to reduce his/her risk by paying with shares. The asymmetry of information favors full share payments, and full cash payments are less probable with large sized transactions. The contractual approach of M\&A terms is supported with a significant positive link between full cash payment and offer premiums. $^{12}$

\section{INSERT TABLE 6}

\footnotetext{
${ }^{12} \mathrm{We}$ also ran a restricted Tobit model of the alternate share/cash payments. The Tobit estimates are not convergent and we cannot discuss their significance. The asymmetry of information seems to go along with share payment. A Logit model (not reported) fits the data even better than the Probit one and get similar results.
} 
The results between the two estimates according the samples of firms in Tables 9 and 10 suggest that the nature of the determinants of the payment changes, particularly if we consider alternate "corner" choices, i.e., full cash or full equity payments. We also use an OLS linear probability model instead of a Probit (see Table 6). The fitted values of the Probit model and of the linear model of the dummy alternate choice between full cash and full share payments are estimated. The correlation between the two fitted values is fairly good $(+0.84) .{ }^{13}$ This means that, although imperfect, a linear estimate of the binary choice is a good proxy for the Probit model. ${ }^{14}$ Therefore, using a linear fitted value to explain the binary choice is acceptable and will later allow us to use a system of two linear equations (instead of a nonlinear system of equation).

\subsubsection{Hybrid payment choice and regimes of payments}

Some determinants may be specific to hybrid means of payments. An estimate of the explaining variable of the cash percentage in hybrid payments is performed using a set of nine variables (Model 1). A restricted set of 4 variables (and no constant) is also considered because of the limited number of mixed payment transactions in our sub-sample (Model 2). Table 7 shows that the percentage paid in cash is negatively linked with the offer premium in Model 1. This is opposite to what is expected. However a positive sign is evidenced in Model 2 estimate. The significant constant means that, on average, a $60 \%$ cash $/ 40 \%$ share mixed payment scheme is considered. Other variables do not seem to be influential (i.e. challenged deals, same sector dummy, acquirer and target $\mathrm{Q}$ ratios).

\section{INSERT TABLE 7}

The cash-share alternative shows explanatory variables different from the hybrid payment setting. In the latter case, the information asymmetry is not significant. It is significant in the all-cash/all-share alternative. Furthermore, the signs of the premium variable are not very

\footnotetext{
${ }^{13}$ We calculated their respective cumulative density functions (cdf). The mean values of the two fitted cdf values using Probit and OLS linear estimates are, respectively, 0.818 and 0.791 ; they have similar standard deviation (0.183 and 0.154).

${ }^{14}$ OLS regressions on dummies may not respect the normality condition for residuals. We checked the normality of the residuals. The skewness test, the kurtosis test and the Bera-Jarque test confirm normality at the $1 \%$ level $(\mathrm{BJ}=95.54, \mathrm{p}=0,00)$. We introduce a linear model for the alternate cash/shares choice because it will simplify the estimate of our two equations system below.
} 
coherent with opposite influences on the propensity to use cash according the regimes of payment. The diversification risk sharing effect determines a corner solution with either full cash or full share payments and has no impact on the choice of hybrid schemes. The size of the transaction negatively impacts a full-cash payment. The deal size is not significant in hybrid payments (when analyzing simple correlations, not reported).

The conclusion we draw from the first step of the analysis is that the means of payment choice is a decision that follows different regimes (Carleton et al., 1983). In given contexts, some determinants are important to justify full cash or share payments. The previous empirics suggest that, for instance, cross country acquisitions and challenged deals are all or nothing conditions that trigger a full-cash payment. Full equity payments are linked with the offer premium. Sellers are paid less in price but more in hopes of future returns by accepting shares on the newly merged firms. Asymmetry of information and risk sharing goals will explain equity payments. These two regimes of payment are "corner solutions". Hybrid payments introduce a continuum between the last two. They develop a complex scheme with a fine tuning of the two core equilibrium variables of the agreement, which are the price and the relative mix of payment.

In the previous tests, cash payments and offer premiums are viewed in a causal framework, with the latter being exogenous. These variables are a coincidental choice in a contractual approach. They cannot be separated when analyzing M\&A transactions. This point is not systematically mentioned in the literature, except by Faccio and Masulis (2005). It is seldom implemented in empirical tests. It implies that the conclusions we derived in the first step of the analysis are questionable because of endogeneity and that some inconsistency may be solved in a larger model of the transactions features.

\subsection{Offer premium}

The offer premium is a well-known term describing M\&A deals. Its determinants are explored in Table 8 . We used a first set of 22 regressors, including a constant and dummies, for means of payment (see regression 1). The latter are significant and show that cash or hybrid payments will go along with higher premiums. However, the percentage of cash payment variable outlines a negative sign (at the $10 \%$ level of significance). The premium increases with the percentage of shares acquired by the bidder. It also appears that challenged 
targets are paid more. We reduced the list of regressors to alternative subsets of 9 or 5 explaining variables (plus a constant, see regressions 2 and 3 in Table 8).

\section{INSERT TABLE 8}

The size of the offer premium increases with the percentage of shares acquired and when the deal is challenged. The percentage of cash payment turns significant and positive, meaning that higher cash payments lead to higher premiums. This is in line with what was expected. The contractual nature of a transaction appears with asymmetry of information: a bidder that is large relative to the target is less exposed to an information risk and will pay a larger premium (significant at the $10 \%$ level in the five variable subset). The target's $\mathrm{Q}$ is no more positively linked with the premium (in the nine variable subset). Opportunity growth at the target level will not enhance the paid premiums. A negative EU zone dummy would mean that intra-European initiators will pay less. Turning insignificant, it does not support the idea that cross-border (i.e., outside Europe initiators) acquisitions will pay higher premiums.

The DISEQ variable is a proxy of disequilibrium in the transaction between the terms offered by the bidder and the strength of the agreement by the seller. For instance, tight conditions will result in a high value of DISEQ. The negative sign associated with that variable effectively shows a link with relatively low (and insufficient) premiums. Thereafter, we will use linear equations to model the offer premiums either in a large definition with 10 independent variables or a restricted list of 6 variables without constant because the latter is non-significant in Table 8.

\subsection{Simultaneous equations}

As long as premiums and means of payment are jointly set, we have to use simultaneous equations (Betton and Eckbo, 2000; Officer, 2003). We distinguish two models to assess the regimes of payment. In each situation there is an endogenous link between the terms of the transactions. ${ }^{15}$ We will consider two linear systems of two equations based on different

\footnotetext{
${ }^{15}$ In a preliminary test, we first estimated a unique system of equations for the global cash/mixed/shares sample. We acknowledge that it ignores the existence of two regimes in the means of payment choice. A positive relationship between the cash percentage and the offer premium is significantly evidenced. This is in line with what was expected. However, the information asymmetry variable is not significant, contrary to expectations. This will illustrate the limit of a unique setting disregarding the regimes of payment.
} 
regimes of means of payment. We still have as dependent variables in each couple of equations the offer premium and the percentage of payment. In the cash/shares regime, the dependent is a dummy for either full cash (1) or full share (0) payments; in the mixed payment regime, the dependent variable is the percentage paid in cash.

\subsubsection{Alternate cash/shares system of equations}

The first system of simultaneous equations has a binary choice as endogenous variable for payments. It is a dummy variable representing the percentage of cash payment for full cash (i.e., 100\%) and full equity (0\%). Here the sample is limited to full cash or full share transactions. The difficulty is that the premium is a continuous variable and the cash payment is a discontinuous variable. We substitute the means of payment equation using the linear continuous proxy identified in Table 6 . The probability to have full cash or full share payment is fitted by a linear OLS form instead of a Probit equation. Using this methodology, we estimate the following system of two linear equations (Panel A in Table 9).

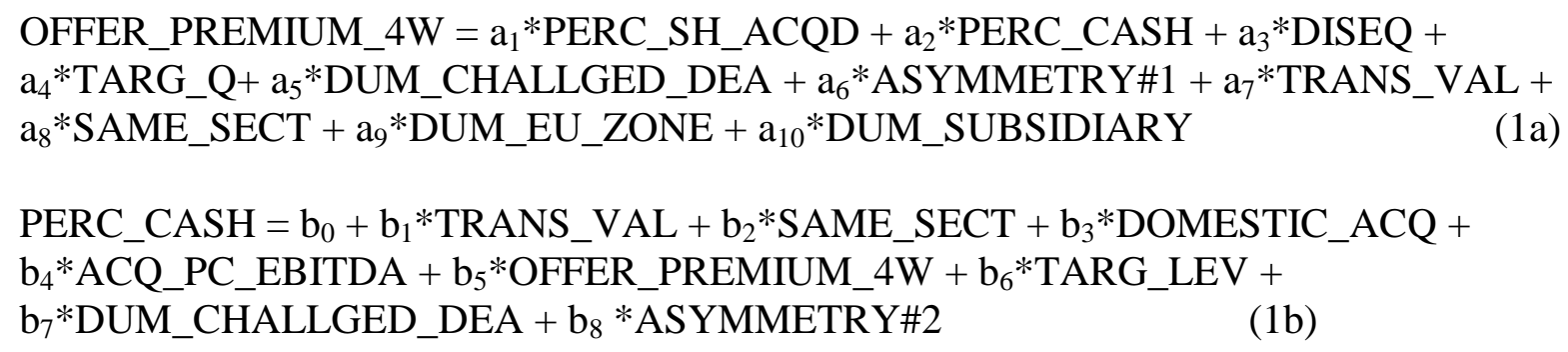

PERC_CASH $=b_{0}+b_{1} *$ TRANS_VAL $+b_{2} *$ SAME_SECT $+b_{3} *$ DOMESTIC_ACQ + $\mathrm{b}_{4} *$ ACQ_PC_EBITDA $+\mathrm{b}_{5} *$ OFFER_PREMIUM_4W + $\mathrm{b}_{6} *$ TARG_LEV + $\mathrm{b}_{7} *$ DUM_CHALLGED_DEA $+\mathrm{b}_{8} *$ ASYMMETRY\# 2

A more limited system of linear equations is also estimated with six explanatory variables for the offer premium instead of ten (Panel B in Table 9).

OFFER_PREMIUM_4W $=\mathrm{a}_{1} *$ PERC_SH_ACQD $+\mathrm{a}_{2} *$ PERC_CASH $+\mathrm{a}_{3} *$ DISEQ + $\mathrm{a}_{4} *$ TARG_Q+ a ${ }_{5}$ DUM_CHALLGED_DEA + $\mathrm{a}_{6} *$ ASYMMETRY1

PERC_CASH $=b_{0}+b_{1} *$ TRANS_VAL $+b_{2} *$ SAME_SECT $+b_{3} *$ DOMESTIC_ACQ + $\mathrm{b}_{4} *$ ACQ_PC_EBITDA + b5*OFFER_PREMIUM_4W + b 6 *TARG_LEV +

$\mathrm{b}_{7} *$ DUM_CHALLGED_DEA $+\mathrm{b}_{8} *$ ASYMMETRY\#2

As mentioned by Officer (2003), we should not use a direct standard linear approach in such a situation. A Probit estimation of the percentage of cash payment is based on a non linear equation of the explanatory variables. Consequently a system of equations fitted to a probit 
mix of payment equation and a linear equation of the offer premium would be non linear. Such a system does not give converging estimates and cannot be tested. ${ }^{16}$

We implemented a two step procedure with an estimate on the offer premium in a univariate first estimate. Then, the fitted value of the offer premium is used as an endogenous variable in the probit equation to fit the cash-share means of payment choice model (Panel $\mathrm{C}$ in Table 9). ${ }^{17}$

The estimates of the linear systems ( $1 \mathrm{a}-\mathrm{b})$ and $(2 \mathrm{a}-\mathrm{b})$ and of the two step procedure are shown in Table 9. A strong and positive relation is identified between the offer premium and the dummy cash/share. It strongly supports the two way relationship between these two variables. The percentage of acquired shares increases with the offer premium. The disequilibrium variable is negative but poorly significant (at the $10 \%$ level Panel C). The dummies for Euro area acquirers, for subsidiary targets or for same sector acquisitions are not significant to explain the size of the premiums. Challenged deals will yield significantly higher premiums. The determinants of the cash/share payment alternative are those previously identified: absolute size of transaction, absence of industry diversification and domestic deals. All of these factors increase the probability of a full share payment. The information asymmetry variable is strongly significant, as expected by the risk sharing theory: the shares payment probability increases with the ASYMMETRY\#2 variable.

\section{INSERT TABLE 9}

The joint setting between the premium and the mode of payment (either all cash or all shares) is made explicit. The cross relation is positive and significant: premiums are higher with cash payments. A full cash offer will pay a premium increased by $17 \%$ compared with a shares payment. Compared to the single equation test, the difference is that the information asymmetry of the deal is no more directly significant in explaining the premium. The cash/share payment is a regime imposed by the risky nature of an acquisition, such as same

\footnotetext{
${ }^{16}$ Our software package algorithm estimates non-linear system of equations but assumes non-zero second order derivatives. This is not the case with a Probit equation with a dependent dummy. Thus, the standard deviations of estimates are not relevant, and we cannot assess the significance of the estimated coefficients

${ }^{17} \mathrm{We}$ also implemented this procedure the other way: a first step gives a fitted dummy for the full cash payment and a second step uses this fitted dummy in the offer premium equation. Results are similar to those reported in Panel C of Table 9.
} 
industry bids, which are more frequently paid by shares. The absence of economic diversification will result in more risky synergies or gains. At the end, asymmetries of information are the driving variable behind the joint choice of the premium paid and the means of payment choice. Results in Table 9 show that large information asymmetry will favor a full share payment, which in turn will lower the offer premium.

In a binary choice between alternate means of payment, it is rather difficult to find a more finely tuned agreement. The bidder can only signal the future value through the premium paid. As a result, the transaction is agreed upon but may present some disequilibrium features. Here the imbalance variable is negative (and moderately significant). It signals that some bidders would have desired to obtain more shares than they effectively obtained. The explanation for the imbalance is simple: they do not pay enough and the premium offered was too small. As expected, the challenged deals are more frequently paid in cash and result in higher premiums.

We can see from Table 9 (Panel A and C) that an important internal cash flow favors cash payment. As Martynova and Renneboog (2009), we do not find a significant or consistent relationship between the bidder's financing decision (particularly through its debt leverage) and the means of payment. If we look at the target's financial situation, no significant relationship between its own debt leverage and cash payment is shown. A leveraged target does not cause the deal to be paid more frequently with cash or with shares. The explanation here could be in conjunction with the non-relevance of the acquirer's debt leverage. In an optimal trade-off financial perspective, the financing decision of the transaction should integrate the target's leverage. The acquisition of a leveraged target should be paid more with shares to limit the side effect of the acquisition on the acquirer's own leverage. Here, the insignificant target's leverage is in line with the non-significance of the acquirer's leverage. It confirms that financing dimension does not directly weigh on payment decision. Debt capacity limitation, whether for the acquirer or the target, does not explain the cash payment scheme. However, our equations assume that the causality goes from financing to payment. We can imagine that a reverse causality (i.e. from payment to subsequent outside financing) may develop in a dynamic framework. $\underline{18}$

\subsubsection{Hybrid payment system}

\footnotetext{
${ }^{18}$ We thank an anonymous referee for that suggestion.
} 
The second system of equations has the percentage of cash payment as the dependent variable. It is estimated only on the sample of hybrid payment transactions. The major drawback of the estimation is the low number of available observations ( $\mathrm{N}=29$ or 43$)$. We first estimate two systems of equations according to the number of independent variables used in the offer premium equation: ten, six or four (respectively, panel $\mathrm{A}$, panel $\mathrm{B}$ and panel $\mathrm{C}$ in Table 10).

OFFER_PREMIUM_4W $=\mathrm{a}_{1} *$ PERC_SH_ACQD $+\mathrm{a}_{2} *$ PERC_CASH $+\mathrm{a}_{3} *$ DISEQ + $\mathrm{a}_{4}$ *TARG_Q+ $\mathrm{a}_{5}$ *DUM_CHALLGED_DEA $+\mathrm{a}_{6} *$ ASYMMETRY\# $1+\mathrm{a}_{7} *$ TRANS_VAL + $\mathrm{a}_{8} *$ SAME_SECT $+\mathrm{a}_{9} *$ DUM_EU_ZONE $+\mathrm{a}_{10} *$ DUM_SUBSIDIARY

PERC_CASH $=b_{0}+b_{1} *$ SAME_SECT $+b_{2} *$ OFFER_PREMIUM_4W $+b_{3} *$ TOEHOLD + $\mathrm{b}_{4} *$ ACQ_Q $+\mathrm{b}_{5} *$ TARG_Q $+\mathrm{b}_{6} *$ DUM_CHALLGED_DEA $+\mathrm{b}_{7} *$ DISEQ + $\mathrm{b}_{8} *$ ASYMMETRY\# $1+\mathrm{b}_{9} *$ ACQ_PC_EBITDA

(3b)

Equation (3a) for the offer premium is similar to equation (1a). Another restricted system is the following:

OFFER_PREMIUM_1W $=\mathrm{a}_{1} *$ PERC_SH_ACQD $+\mathrm{a}_{2} *$ PERC_CASH $+\mathrm{a}_{3} *$ DISEQ + $\mathrm{a}_{4} *$ TARG_Q $+\mathrm{a}_{5} *$ DUM_CHALLGED_DEA $+\mathrm{a}_{6} *$ ASYMMETRY\# 1

PERC_CASH $=b_{0}+b_{1} *$ SAME_SECT $+b_{2} *$ OFFER_PREMIUM_1 $\mathrm{W}+b_{3} *$ TOEHOLD + $\mathrm{b}_{4} *$ ACQ_Q $+\mathrm{b}_{5} *$ TARG_Q $+\mathrm{b}_{6} *$ DUM_CHALLGED_DEA $+\mathrm{b}_{7} *$ DISEQ + $\mathrm{b}_{8} *$ ASYMMETRY\#1

Better results will be yielded by a more restricted system (Panel C):

OFFER_PREMIUM_1W $=\mathrm{a}_{1} *$ PERC_SH_ACQD $+\mathrm{a}_{2} *$ TARG_Q+ a3*TRANS_VAL+ $\mathrm{a}_{4} *$ DUM_CHALLGED_DEA

PERC_CASH $=b_{1} *$ OFFER_PREMIUM_4W $+b_{2} * S A M E \_S E C T ~+b_{3} * A C Q \_P C \_E B I T D A ~+$ $\mathrm{b}_{4}{ }^{*}$ ASYMMETRY\#1

The result in panels A and B of Table 10 do not show a positive relationship between the offer premium and the cash percentage in mixed payment schemes. The offer premiums are positively influenced by the size of the block of acquired shares, by the challenging status of the deal and by the target's $Q$ value. The latter underlines the importance of growth 
opportunities at the target's level. The percentage of cash in the payment does not depend significantly on any variables. The result of our estimate on the hybrid sample is poor. The low number of observations and the large number of independent variables reduces the probability of a variable to appear significant. In particular, the asymmetry of information is not found to be significant.

\section{INSERT TABLE 10}

We tried to limit the number of variables to increase the number of degrees of freedom. In panel $\mathrm{C}$ of Table 10, we reduced the number of regressors. We considered four variables in the premium equation and in the cash payment equation. We then obtained better results: offer premiums are positively correlated with the percentage of shares acquired (PERC_SH_ACQ), the opportunities and latent synergies at the target's level (TARG_Q). The percentage of cash is now positively linked with the offer premium, highlighting a contractual trade-off. This result is in line with the hypothesis. The result changed compared with the univariate estimates in Table 7 , where a negative significant relationship was evidenced in regression (1). The economic diversification also influences the deal but is not in line with the contractual approach. The significant sign of the acquirer's cash flow variable shows that the financial situation of the acquirers also conditions the setting of the mix of payment in the expected way. However, the asymmetry of information does not influence the cash percentage setting in hybrid payment transactions. The quality of the estimates of the cash percentage equation in panel $\mathrm{C}$ has improved but remains poor.

How should the absence of a significant relationship with the asymmetry of information variable in the case of hybrid M\&A be interpreted? We already mentioned the small size of the hybrid sample. Moreover, the simultaneous equation system underlines a complex equilibrium in which many variables are endogenous. The cash payment consideration and bid premium interact strongly and positively. The one equation test of the cash percentage in hybrid payments evidenced a non-significant relationship with the asymmetry of information (see Table 7). The sign of this variable remains not significant in the hybrid system of equations. However, it stays negative and becomes more significant (from the $10 \%$ to the $1 \%$ level) to explain the choice of payment in the alternate cash/share sample (see Table 9). We conjecture that the asymmetry of information is lower in hybrid payment schemes because of 
delivered information through the judicious setting of the percentage paid in cash, as suggested in La Bruslerie (2012). The sample is a cross section of successful acquisitions with conditions that are apparently satisfying for the parties. The premiums seem fair as the imbalance offer variable is not significant (see panels A or B). An imbalanced situation in which the bidder does not obtain the number of shares he wants is not evidenced. This is a strong difference with the test for alternate cash/share payments.

Hybrid payment schemes allow a fine tuning when there is more information available regarding the characteristics of the transaction. Even if a negotiation does not formally exist in a tender offer, when using a mixed scheme of payment, the bidder should integrate not only his/her interest but also the seller's. He/she knows that the percentage of cash is screened by the seller. We draw the conclusion that the transaction terms, particularly the percentage paid in cash, reflect some equilibrium in sharing the risk about the future uncertain value of the acquisition.

\section{Conclusion}

The analysis of the offer premiums and of the means of payment should not be performed by considering one variable as exogenous and explicative of the other. We show that these two variables are jointly set up in a contractual approach. More precisely, the relationship between the cash means of payment and the offer premium is positive: higher premiums will yield mixed payment with more cash. A trade-off equilibrium develops: when the seller wants to be paid more, he/she should accept to be paid less in potential future returns (i.e., in new equity shares). The risk sharing nature of an M\&A agreement is confirmed and influences the means of payment. The double risk situation relies on a double asymmetry of information between the buyer and the seller, as identified by Hansen (1987). The choice of means of payment is a complex decision that can be done in alternate terms of full cash or full share payments. Hybrid payments follow a different rationale. The fine tuning of the percentage paid in cash is also an important term in a successful transaction and helps in delivering information.

Considering a sample of European M\&As over the 2000-2010 decade, the determinants of the means of payment choice are known and confirmed. Firms with a high growth potential and a high stock value are not particularly prone to finance an acquisition with equity. The growth 
opportunities of the target will enhance the paid premiums. In line with the results of Martynova and Renneboog (2009), the financing decision at the acquirer's level does not seem significant: the acquirer's leverage ratio does not explain the mix of payment. However, a cash availability hypothesis is supported by our data. It explains the use of full cash consideration, and more cash in mixed cash-share payments. This opportunistic financing decision embedded in the transaction will not modify the subsequent leverage ratio. Another alternate explanation, for instance when there is no cash flow availability, is that the payment decision by cash may subsequently influence the financing decision by issuing more debt or by selling new shares. A dynamic model of acquisition financing may be explored in case of cash payment with a focus not on prior financing conditions but on posterior leverage.

As a result, we show that an empirical analysis should not be performed on a global sample mixing any regime of payment. Full cash and full share payments are corner solutions that will yield different levels of equilibrium between parties. The determinants of the transaction terms are not the same, and we identified two regimes of payment. Blending all the deals in one sample will assume that a continuum exists from full cash to all-shares payments. Running regressions even through a simultaneous setting on a global sample can be misleading. This will ignore the difference of regimes of payments and the results may be spurious. The existence of regimes of payment in M\&A transactions is the first conclusion. We tested the different sets of determinants of M\&A terms in a contractual approach in which the offer premium and the means of payment are set jointly. The underlying rationale of asymmetry of information and risk sharing calculus explains the contractual approach. It combines well with known factors, such as cross border acquisitions, competitive transactions or the absolute size of the target, all of which favor cash payment. However, the limited number of hybrid deals in our sample would justify further development. 
Table 1

Descriptive statistics of European M\&A 2000-2010. Sample of 432 transactions after exclusion of squeeze out and buyback programs of the original sample of 528 deals, period 2000-2010; deal values in current million USD, European target transactions, target firms incorporated in Italy, France, the UK, the Netherlands, Germany, Spain and Belgium; Intra European country: target and initiator are from the same country; Intra EU: initiators coming from one of the 6 other countries of the sample; Cross border: initiator incorporated in North America (USA and Canada) or Japan; US acquirers are distinguished; source Thomson One Banker.

\begin{tabular}{|c|c|c|c|c|c|c|c|c|c|}
\hline \multicolumn{10}{|c|}{ Panel A Number and value by means of payment } \\
\hline & \multicolumn{3}{|c|}{ Number } & \multicolumn{4}{|c|}{ Total value } & \multicolumn{2}{|c|}{ Av. deal size } \\
\hline Cash & 294 & \multicolumn{2}{|l|}{$68.1 \%$} & \multicolumn{2}{|c|}{365192} & \multicolumn{2}{|c|}{$40.7 \%$} & \multicolumn{2}{|c|}{1242.15} \\
\hline Hybrid & 62 & \multicolumn{2}{|l|}{$14.4 \%$} & \multicolumn{2}{|l|}{211775} & \multicolumn{2}{|c|}{$23.6 \%$} & \multicolumn{2}{|c|}{3415.72} \\
\hline Shares & 76 & $17.6 \%$ & & \multicolumn{2}{|l|}{321091} & 35.89 & & \multicolumn{2}{|c|}{4224.89} \\
\hline Total & 432 & & & 898058 & & & & & \\
\hline \multicolumn{10}{|c|}{ Panel B Domestic and cross border deals } \\
\hline & & Cash & $(\%)$ & Hybrid & $(\%)$ & Shares & $(\%)$ & Total & $(\%)$ \\
\hline \multicolumn{2}{|c|}{$\begin{array}{l}\text { Intra European } \\
\text { country }\end{array}$} & 137 & $58.5 \%$ & 43 & $18.4 \%$ & 54 & $23.1 \%$ & 234 & $54.2 \%$ \\
\hline \multicolumn{2}{|c|}{ Intra Europe Union } & 81 & $76.4 \%$ & 8 & $7.5 \%$ & 17 & $16.0 \%$ & 106 & $24.5 \%$ \\
\hline \multicolumn{2}{|c|}{$\begin{array}{l}\text { Cross border US } \\
\text { acquirer }\end{array}$} & 35 & $74.5 \%$ & 7 & $14.9 \%$ & 5 & $10.6 \%$ & 47 & $10.9 \%$ \\
\hline \multicolumn{2}{|c|}{$\begin{array}{l}\text { Cross border non US } \\
\text { acquirer }\end{array}$} & 41 & $91.1 \%$ & 4 & $8.9 \%$ & 0 & $0.0 \%$ & 45 & $10.4 \%$ \\
\hline \multicolumn{2}{|c|}{ Total } & 294 & $68.1 \%$ & 62 & $14.4 \%$ & 76 & $17.6 \%$ & 432 & $100.0 \%$ \\
\hline
\end{tabular}

Table 2

Offer premium by mean of payment. Premium in \%, 432 European transactions, period 20002010, premiums are calculated using the stock price 1 day before the announcement of the transaction; source: Thomson One Banker.

\begin{tabular}{llll}
\hline Offer premium & Cash & Hybrid & Shares \\
\hline Average & 25.53 & 27.80 & 17.29 \\
Median & 17.28 & 21.99 & 12.45 \\
1st quart & 6.95 & 10.40 & 4.37 \\
3rd quart & 38.74 & 41.94 & 31.57 \\
$\mathrm{~N}$ & 217 & 49 & 55 \\
t-test & cash vs. shares & cash vs. hybrid & hybrid vs. shares \\
p-value & 0.078 & 0.574 & 0.057 \\
\hline
\end{tabular}


Table 3 Descriptive statistics of the variables. Variables are filtered; observations above the 99\% and below the 1\% distribution eliminated for the ASYMMETRY\#1, ASYMMETRY\#2, TARG_Q, ACQ_Q, ACQ_LEV, TARG_LEV, OFFER_PREMIUM_4W variables, variable definitions, see Appendix.

\begin{tabular}{|c|c|c|c|c|c|}
\hline Variable & Nb Obs. & Mean & $\begin{array}{l}\text { Standard } \\
\text { deviation }\end{array}$ & Minimum & Maximum \\
\hline Acquirer cash holding & 417 & 4268.3931 & 47547.7185 & 0.0060 & 966677.8710 \\
\hline Acquirer EBITDA & 422 & 4361.2206 & 35518.5197 & -686.9000 & 707896.9590 \\
\hline Acquirer debt leverage & 413 & 0.2755 & 1.7507 & -7.2377 & 31.6685 \\
\hline Acquirer market value & 306 & 16992.8120 & 35820.3673 & 7.3350 & 446828.4730 \\
\hline Acquirer net assets & 424 & 18910.2834 & 202762.2048 & -1021.5450 & 4104939.1990 \\
\hline Acquirer net debt & 423 & 3555.8100 & 57384.7745 & -959364.8320 & 597080.3370 \\
\hline Acquirer cash holding & 417 & 11.8988 & 73.8880 & 0.0001 & 1015.2740 \\
\hline Acquirer percent EBITDA & 403 & 15.0808 & 131.2810 & 0.0003 & 2460.0518 \\
\hline Acquirer $Q$ ratio & 275 & 3.6032 & 5.0729 & -8.2937 & 43.8388 \\
\hline Asymmetry \#1 & 398 & 0.6816 & 1.3061 & 0.0017 & 10.3594 \\
\hline Asymmetry \#2 & 414 & 0.9845 & 1.8186 & 0.0001 & 15.1577 \\
\hline DISEQ & 479 & 1.8823 & 7.3729 & -51.7620 & 65.4400 \\
\hline $\begin{array}{l}\text { Domestic acquisition } \\
\text { dummy }\end{array}$ & 528 & 0.6042 & 0.4895 & 0 & 1 \\
\hline $\begin{array}{l}\text { Pure cash payment } \\
\text { dummy }\end{array}$ & 528 & 0.5549 & 0.4974 & 0 & 1 \\
\hline $\begin{array}{l}\text { Challenged deal dummy } \\
\text { Euro area acquirer }\end{array}$ & 528 & 0.0606 & 0.2388 & 0 & 1 \\
\hline dummy & 528 & 0.6439 & 0.4793 & 0 & 1 \\
\hline Mixed payment dummy & 528 & 0.1098 & 0.3130 & 0 & 1 \\
\hline $\begin{array}{l}\text { Pure share payment } \\
\text { dummy }\end{array}$ & 528 & 0.1534 & 0.3607 & 0 & 1 \\
\hline Subsidiary target dummy & 528 & 0.1913 & 0.3937 & 0 & 1 \\
\hline Toehold dummy & 528 & 0.3011 & 0.4592 & 0 & 1 \\
\hline ROA & 418 & 0.0914 & 0.0871 & 0.0020 & 1.0070 \\
\hline Enterprise value & 503 & 7745.4877 & 25648.6558 & 13.0360 & 442807.6090 \\
\hline Equity value & 504 & 6432.4035 & 23458.5490 & 52.0780 & 432124.5420 \\
\hline Friendly attitude dummy & 528 & 0.6742 & 0.4691 & 0.0000 & 1.0000 \\
\hline $\begin{array}{l}\text { Offer premium } \\
\text { Acquirer percentage of }\end{array}$ & 415 & 30.2921 & 33.9966 & -53.7900 & 186.0400 \\
\hline $\begin{array}{l}\text { issued shares } \\
\text { Percentage of cash }\end{array}$ & 418 & 7.9152 & 16.2923 & 0.0000 & 96.9700 \\
\hline payment & 432 & 74.1572 & 40.5682 & 0 & 100.0000 \\
\hline $\begin{array}{l}\text { Percentage of acquired } \\
\text { target shares }\end{array}$ & 483 & 58.0259 & 39.7593 & 0.2620 & 100.0000 \\
\hline Percentage sought & 500 & 61.1850 & 39.7712 & 0.2940 & 100.0000 \\
\hline Same sector dummy & 528 & 0.5814 & 0.4938 & 0.0000 & 1.0000 \\
\hline Target debt leverage & 491 & 0.0946 & 0.2311 & -0.8834 & 0.6701 \\
\hline Target net assets & 520 & 2332.6581 & 6395.0014 & -5520.8350 & 91946.0490 \\
\hline Target cash holding & 513 & 1.2113 & 6.0299 & 0.0001 & 93.9707 \\
\hline Target $Q$ ratio & 485 & 3.2921 & 4.2978 & 0.3750 & 34.6180 \\
\hline Toehold percentage & 528 & 14.1002 & 26.9098 & 0.0000 & 99.4570 \\
\hline Transaction value & 528 & 1804.0272 & 6586.9736 & 50.2420 & 75960.8470 \\
\hline
\end{tabular}




\section{Table 4}

Expected sign between the percentages paid in cash and the offer premium and possible determinants according to three main theoretical approaches: Financial constraint theory, asymmetry of information and contract theory, environment and firm characteristics; AI: asymmetry of information; ns: no sense)

\begin{tabular}{|c|c|c|c|c|c|c|}
\hline Dependant variable & & $\begin{array}{l}\text { Cash } \\
\text { Percentage }\end{array}$ & & & $\begin{array}{l}\text { Offer } \\
\text { Premium }\end{array}$ & \\
\hline Determinants & $\begin{array}{l}\text { Financial } \\
\text { constraint }\end{array}$ & $\begin{array}{l}\text { Contractual } \\
\quad \& \mathrm{Al}\end{array}$ & Environment & $\begin{array}{l}\text { Financial } \\
\text { constraint }\end{array}$ & $\begin{array}{l}\text { Contractual } \\
\& \mathrm{Al}\end{array}$ & Environment \\
\hline $\begin{array}{l}\text { Percentage of acquired } \\
\text { shares }\end{array}$ & - & & & & & \\
\hline Transaction value & - & & & - & & \\
\hline Same sector & & - & & & & \\
\hline Domestic acquisition & & & - & & & - \\
\hline Acquirer percent. EBITDA & + & & & & & \\
\hline Target cash holding & + & & & + & & \\
\hline Friendly attitude & & - & - & & & - \\
\hline Offer premium & & + & & ns & ns & ns \\
\hline Toehold & & + & & & + & \\
\hline ROA & + & & & + & & \\
\hline Acquirer leverage & - & & & & & \\
\hline Target leverage & - & & & & & \\
\hline Acquirer MTB & - & & & + & & \\
\hline Target MTB & & $+/-$ & & & + & \\
\hline Challenged deal & & & + & & & + \\
\hline Percentage sought & - & & & & & \\
\hline Subsidiary target & & + & & & + & \\
\hline Asymmetry variable & & - & & & - & \\
\hline Imbalanced offer & & & & & - & \\
\hline $\begin{array}{l}\text { Acquirer percentage of } \\
\text { issued shares }\end{array}$ & & & + & & & \\
\hline $\begin{array}{l}\text { Percentage of cash } \\
\text { payment }\end{array}$ & ns & ns & ns & & + & \\
\hline
\end{tabular}


Table 5 - Determinants of ordinal choices between cash, hybrid and shares payments

(Ordered values: Cash(2), Hybrid(1), Shares(0); regressions (1) and (2): ordered Logit; regressions (3) and(4): multinomial Logit estimates; cuts for Logit are estimated limits between classes; multinomial model is joint estimates of cash vs. hybrid alternate choice and cash vs. shares choice; robust covariance estimate are used to adjust for heteroscedasticity; variables definition: see Appendix; coefficient p-values between parenthesis; European M\&A transactions; 2000-2010; a: 1\% significance level; b: 5\% significance level; c: 10\% significance level)

\begin{tabular}{|c|c|c|c|c|c|c|c|c|}
\hline \multirow[t]{2}{*}{ Ordered Logit } & & & \multicolumn{3}{|l|}{ Multinomial } & \multicolumn{3}{|l|}{ Multinomial } \\
\hline & & & Cash vs. Hybrid & & & Cash vs. Shares & & \\
\hline Variable & (1) & (2) & Variable & (3) & (4) & Variable & (3) & (4) \\
\hline Constant & $\begin{array}{l}3.5612 \\
\left(0.00^{\mathrm{a}}\right)\end{array}$ & $\begin{array}{l}2.0638 \\
\left(0.00^{\mathrm{a}}\right)\end{array}$ & Constant & $\begin{array}{l}2.0647 \\
(0.75)\end{array}$ & $\begin{array}{l}-0.2206 \\
(0.80)\end{array}$ & Constant & $\begin{array}{l}4.1162 \\
\left(0.00^{\mathrm{a}}\right)\end{array}$ & $\begin{array}{l}1.5028 \\
\left(0.00^{\mathrm{a}}\right)\end{array}$ \\
\hline Transaction value & $\begin{array}{l}0.0000 \\
\left(0.02^{b}\right)\end{array}$ & $\begin{array}{l}0.0000 \\
\left(0.04^{\mathrm{b}}\right)\end{array}$ & Transaction value & $\begin{array}{l}-0.0000 \\
(0.73)\end{array}$ & $\begin{array}{l}-0.0000 \\
(0.81)\end{array}$ & Transaction value & $\begin{array}{l}-0.0001 \\
(0.13)\end{array}$ & $\begin{array}{l}-0.0000 \\
(0.41)\end{array}$ \\
\hline Same sector dummy & $\begin{array}{l}-0.8369 \\
\left(0.05^{b}\right)\end{array}$ & & Same sector dummy & $\begin{array}{l}-0.1400 \\
(0.95)\end{array}$ & & Same sector dummy & $\begin{array}{l}-0.6752 \\
(0.39)\end{array}$ & \\
\hline $\begin{array}{l}\text { Domestic acquisition } \\
\text { dummy }\end{array}$ & $\begin{array}{l}-1.5989 \\
\left(0.00^{\mathrm{a}}\right)\end{array}$ & & $\begin{array}{l}\text { Domestic acquisition } \\
\text { dummy }\end{array}$ & $\begin{array}{l}-0.2140 \\
(0.93)\end{array}$ & & $\begin{array}{l}\text { Domestic acquisition } \\
\text { dummy }\end{array}$ & $\begin{array}{l}-1.6577 \\
\left(0.07^{\mathrm{C}}\right)\end{array}$ & \\
\hline Offer premium & $\begin{array}{l}0.0087 \\
(0.32)\end{array}$ & $\begin{array}{l}0.0077 \\
(0.25)\end{array}$ & Offer premium & $\begin{array}{l}0.0260 \\
(0.65)\end{array}$ & $\begin{array}{l}0.0275 \\
(0.36)\end{array}$ & Offer premium & $\begin{array}{l}0.0299 \\
(0.11)\end{array}$ & $\begin{array}{l}0.0263 \\
\left(0.01^{b}\right)\end{array}$ \\
\hline ROA & $\begin{array}{l}-2.4884 \\
(0.42)\end{array}$ & & ROA & $\begin{array}{l}4.7299 \\
(0.82)\end{array}$ & & ROA & $\begin{array}{l}-3.2536 \\
(0.13)\end{array}$ & \\
\hline Acquirer leverage & $\begin{array}{l}0.1267 \\
(0.70)\end{array}$ & & Acquirer leverage & $\begin{array}{l}-0.0138 \\
(0.99)\end{array}$ & & Acquirer leverage & $\begin{array}{l}0.1035 \\
(0.92)\end{array}$ & \\
\hline Target leverage & $\begin{array}{l}-0.8286 \\
(0.51)\end{array}$ & $\begin{array}{l}1.1022 \\
(0.11)\end{array}$ & Target leverage & $\begin{array}{l}-3.7854 \\
(0.65)\end{array}$ & $\begin{array}{l}0.2111 \\
(0.92)\end{array}$ & Target leverage & $\begin{array}{l}-3.5510 \\
(0.13)\end{array}$ & $\begin{array}{l}0.8199 \\
(0.35)\end{array}$ \\
\hline Acquirer $Q$ ratio & $\begin{array}{l}0.0541 \\
(0.62)\end{array}$ & $\begin{array}{l}0.0310 \\
(0.49)\end{array}$ & Acquirer $Q$ ratio & $\begin{array}{l}-0.0386 \\
(0.97)\end{array}$ & $\begin{array}{l}0.0163 \\
(0.96)\end{array}$ & Acquirer $Q$ ratio & $\begin{array}{l}0.2127 \\
(0.17)\end{array}$ & $\begin{array}{l}0.2015 \\
\left(0.00^{\mathrm{a}}\right)\end{array}$ \\
\hline Target $Q$ ratio & $\begin{array}{l}-0.0733 \\
(0.18)\end{array}$ & $\begin{array}{l}-0.0968 \\
\left(0.05^{b}\right)\end{array}$ & Target $Q$ ratio & $\begin{array}{l}-0.7564 \\
(0.82)\end{array}$ & $\begin{array}{l}-0.1181 \\
(0.78)\end{array}$ & Target $Q$ ratio & $\begin{array}{l}-0.1833 \\
\left(0.02^{b}\right)\end{array}$ & $\begin{array}{l}-0.1260 \\
\left(0.03^{\mathrm{b}}\right)\end{array}$ \\
\hline
\end{tabular}




\begin{tabular}{|c|c|c|c|c|c|c|c|c|}
\hline Challenged deal dummy & $\begin{array}{l}0.3559 \\
(0.68)\end{array}$ & & Challenged deal dummy & $\begin{array}{l}26.1383 \\
\left(0.00^{a}\right)\end{array}$ & & Challenged deal dummy & $\begin{array}{l}25.5263 \\
\left(0.00^{\mathrm{a}}\right)\end{array}$ & \\
\hline Subsidiary target dummy & $\begin{array}{l}0.7860 \\
(0.21)\end{array}$ & & Subsidiary target dummy & $\begin{array}{l}1.3403 \\
(0.69)\end{array}$ & & Subsidiary target dummy & $\begin{array}{l}1.6004 \\
(0.21)\end{array}$ & \\
\hline Asymmetry\#1 & $\begin{array}{l}-0.2614 \\
(0.26)\end{array}$ & $\begin{array}{l}-0.6072 \\
\left(0.00^{\mathrm{a}}\right)\end{array}$ & Asymmetry\#2 & $\begin{array}{l}-0.1024 \\
(0.81)\end{array}$ & $\begin{array}{l}-0.0926 \\
(0.49)\end{array}$ & Asymmetry\#2 & $\begin{array}{l}-0.8616 \\
\left(0.01^{\mathrm{b}}\right)\end{array}$ & $\begin{array}{l}-0.9201 \\
\left(0.00^{a}\right)\end{array}$ \\
\hline Cut(1) & $\begin{array}{l}-0.3035 \\
(0.21)\end{array}$ & $\begin{array}{l}-0.0844 \\
(0.64)\end{array}$ & & & & & & \\
\hline Cut(2) & $\begin{array}{l}1.0000 \\
\left(0.00^{\mathrm{a}}\right)\end{array}$ & $\begin{array}{l}1.0000 \\
\left(0.00^{\mathrm{a}}\right)\end{array}$ & & & & & & \\
\hline $\mathrm{N}$ & 171 & 206 & $\mathrm{~N}$ & 173 & 210 & & & \\
\hline Log likelihood & -118.86 & -163.31 & Log likelihood & -101.78 & -153.84 & & & \\
\hline
\end{tabular}


Table 6- Determinants of alternate cash-shares choice

(Dependant is dummy full cash(1)/full share(0) payment; restricted model with 8 variables; Probit estimates; robust covariance estimate are used to adjust for heteroscedasticity; variable definitions: see Appendix; coefficient p-values between parenthesis; European M\&A transactions; 2000-2010; a: 1\% significance level; b: 5\% significance level; c: 10\% significance level)

\begin{tabular}{llll}
\hline \multicolumn{2}{l}{$\begin{array}{l}\text { Restricted cash(1)/share(0) alternative } \\
\text { probit }\end{array}$} & OLS estimate & \\
\hline Variable & Coefficient & Variable & Coefficient \\
\hline Constant & 0.7072 & Constant & 0.9144 \\
& $\left(0.00^{\mathrm{a}}\right)$ & & $\left(0.00^{\mathrm{a}}\right)$ \\
Transaction value & -0.0000 & Transaction value & -0.0000 \\
& $\left(0.02^{\mathrm{b}}\right)$ & & $\left(0.00^{\mathrm{a}}\right)$ \\
Same sector dummy & -0.3592 & Same sector dummy & -0.0757 \\
& $\left(0.08^{\mathrm{c}}\right)$ & & $\left(0.08^{\mathrm{c}}\right)$ \\
Domestic acquisition dummy & -0.4293 & Domestic acquisition dummy & -0.0938 \\
& $\left(0.04^{\mathrm{b}}\right)$ & & $\left(0.03^{\mathrm{b}}\right)$ \\
Acquirer EBITDA(\%) & 0.1937 & Acquirer EBITDA(\%) & 0.0000 \\
& $\left(0.00^{\mathrm{a}}\right)$ & & $\left(0.01^{\mathrm{b}}\right)$ \\
Offer premium & 0.0116 & Offer premium & 0.0013 \\
& $\left(0.01^{\mathrm{a}}\right)$ & & $\left(0.04^{\mathrm{b}}\right)$ \\
Target leverage & 0.9124 & Target leverage & 0.0562 \\
& $\left(0.07^{\mathrm{c}}\right)$ & & $(0.57)$ \\
Challenged deal dummy & 1.4492 & Challenged deal dummy & 0.1574 \\
& $\left(0.00^{\mathrm{b}}\right)$ & & $\left(0.00^{\mathrm{a}}\right)$ \\
Asymmetry\#2 & -0.1320 & Asymmetry\#2 & -0.0688 \\
& $\left(0.08^{\mathrm{c}}\right)$ & & $\left(0.01^{\mathrm{a}}\right)$ \\
$\mathrm{N}$ & & & \\
Log likelihood & 265 & $\mathrm{~N}$ & 265 \\
& -94.74 & R2 & 0.16 \\
\hline
\end{tabular}


Table 7 - Determinants of hybrid payment choices

(Dependent: percentage paid in cash in hybrid transactions; OLS estimates; robust covariance estimate are used to adjust for heteroscedasticity; variables definition: see Appendix; coefficient pvalues between parenthesis; European M\&A transactions; 2000-2010; N=32; a: $1 \%$ significance level; b: 5\% significance level; c: 10\% significance level)

\begin{tabular}{lll}
\hline Regressions & $(1)$ & $\underline{(2)}$ \\
\hline Constant & 60.5234 & \\
& $\left(0.00^{\mathrm{a}}\right)$ & \\
Same sector dummy & -2.5217 & 22.1202 \\
& $(0.74)$ & $\left(0.01^{\mathrm{a}}\right)$ \\
Offer premium & -0.2452 & 0.3782 \\
& $\left(0.04^{\mathrm{b}}\right)$ & $\left(0.03^{\mathrm{b}}\right)$ \\
Toehold & 0.4225 & \\
& $\left(0.00^{\mathrm{a}}\right)$ & \\
Acquirer Q ratio & -0.9708 & \\
& $(0.43)$ & \\
Target Q ratio & 2.6948 & \\
& $(0.41)$ & \\
Challenged deal dummy & 0.2462 & \\
& $(0.98)$ & \\
Imbalance offer & -1.5573 & \\
& $(0.24)$ & \\
Asymmetry \#1 & -2.2314 & 7.8061 \\
& $(0.43)$ & $(0.34)$ \\
Acquirer EBITDA & -5.9457 & 9.3749 \\
& $\left(0.00^{\mathrm{a}}\right)$ & $\left(0.00^{\mathrm{a}}\right)$ \\
$\mathrm{N}$ & & \\
R2 & 29 & 48 \\
\hline
\end{tabular}


Table 8 - Determinants of the offer premiums

(Dependant is offer premium in percentage calculated 1 week before the announcement; OLS estimates; robust covariance estimate are used to adjust for heteroscedasticity; variable definitions: see Appendix; coefficient p-values between parenthesis; European M\&A transactions; 2000-2010; $\mathrm{N}=\mathrm{a}: 1 \%$ significance level; b: $5 \%$ significance level; c: $10 \%$ significance level)

\begin{tabular}{|c|c|c|c|}
\hline Dependant Premium & (1) & (2) & (3) \\
\hline Constant & $\begin{array}{l}18.9747 \\
(0.15)\end{array}$ & $\begin{array}{l}10.1368 \\
(0.22)\end{array}$ & $\begin{array}{l}5.8985 \\
(0.35)\end{array}$ \\
\hline Percentage acquired shares & $\begin{array}{l}0.1918 \\
\left(0.03^{b}\right)\end{array}$ & $\begin{array}{l}0.2132 \\
\left(0.00^{\mathrm{a}}\right)\end{array}$ & $\begin{array}{l}0.2426 \\
\left(0.00^{\mathrm{a}}\right)\end{array}$ \\
\hline Same sector dummy & $\begin{array}{l}3.1224 \\
(0.46)\end{array}$ & $\begin{array}{l}2.2008 \\
(0.49)\end{array}$ & \\
\hline Domestic acquisition dummy & $\begin{array}{l}-3.2434 \\
(0.44)\end{array}$ & & \\
\hline Euro area acquirer dummy & $\begin{array}{l}-12.7912 \\
\left(0.08^{c}\right)\end{array}$ & $\begin{array}{l}-7.2106 \\
(0.12)\end{array}$ & \\
\hline Acquirer cash holding & $\begin{array}{l}-0.1000 \\
(0.74)\end{array}$ & & \\
\hline Acquirer EBITDA(\%) & $\begin{array}{l}-0.4087 \\
(0.42)\end{array}$ & & \\
\hline Target cash holding & $\begin{array}{l}0.5647 \\
(0.19)\end{array}$ & & \\
\hline Friendly attitude & $\begin{array}{l}-2.9946 \\
(0.58)\end{array}$ & & \\
\hline Percentage cash payment & $\begin{array}{l}-0.4118 \\
\left(0.10^{\circ}\right)\end{array}$ & $\begin{array}{l}0.1246 \\
\left(0.00^{\mathrm{a}}\right)\end{array}$ & $\begin{array}{l}0.1202 \\
\left(0.01^{b}\right)\end{array}$ \\
\hline Toehold dummy & $\begin{array}{l}-4.3769 \\
(0.47)\end{array}$ & & \\
\hline Imbalance offer & $\begin{array}{l}-0.5917 \\
\left(0.03^{b}\right)\end{array}$ & $\begin{array}{l}-0.3672 \\
\left(0.06^{\mathrm{C}}\right)\end{array}$ & $\begin{array}{l}-0.3546 \\
\left(0.07^{\circ}\right)\end{array}$ \\
\hline ROA & $\begin{array}{l}-55.8191 \\
(0.20)\end{array}$ & & \\
\hline Acquirer leverage & $\begin{array}{l}1.2165 \\
(0.65)\end{array}$ & & \\
\hline Target leverage & $\begin{array}{l}5.5111 \\
(0.66)\end{array}$ & & \\
\hline Acquirer $Q$ ratio & $\begin{array}{l}-0.1340 \\
(0.80)\end{array}$ & & \\
\hline Target $Q$ ratio & $\begin{array}{l}1.1916 \\
\left(0.10^{c}\right)\end{array}$ & $\begin{array}{l}0.6058 \\
(0.30)\end{array}$ & \\
\hline Challenged deal dummy & $\begin{array}{l}19.5157 \\
(0.01 a)\end{array}$ & $\begin{array}{l}20.3196 \\
(0.01 a)\end{array}$ & $\begin{array}{l}19.3759 \\
(0.01 b)\end{array}$ \\
\hline Subsidiary target dummy & $\begin{array}{l}-10.6534 \\
(0.19)\end{array}$ & $\begin{array}{l}-2.9304 \\
(0.53)\end{array}$ & \\
\hline Pure cash payment dummy & $\begin{array}{l}59.3480 \\
\left(0.01^{\mathrm{b}}\right)\end{array}$ & & \\
\hline Mixed payment dummy & $\begin{array}{l}26.0063 \\
\left(0.03^{b}\right)\end{array}$ & & \\
\hline Asymmetry \#1 & $\begin{array}{l}0.5132 \\
(0.82)\end{array}$ & $\begin{array}{l}-1.6136 \\
(0.16)\end{array}$ & $\begin{array}{l}-2.0617 \\
\left(0.09^{c}\right)\end{array}$ \\
\hline $\mathrm{N}$ & 151 & 306 & 311 \\
\hline $\mathrm{R} 2$ & 0.33 & 0.19 & 0.17 \\
\hline
\end{tabular}


Table 9 - Determinants of offer premiums and full cash/full share payments - Simultaneous linear equation estimates

(Dependants are offer premiums in percentage calculated 4 week before the announcement and cash payment (either $0 \%$ or $100 \%$ ); linear system of two equations; Percentage cash payment is 0 or $100 \%$; see equations (1ab) and (2a-b) in the text; robust covariance estimate are used to adjust for heteroscedasticity; variable definitions: see Appendix; Panels A and B uses linear equation to fit the percentage of cash payment; Panel C uses a two step procedure: offer premium is estimated first using OLS and in a second stepe Probit is estimated using the fitted value of the offer premium; European M\&A transactions; 2000-2010; a: 1\% significance level; b: 5\% significance level; c: $10 \%$ significance level)

\begin{tabular}{|c|c|c|c|c|c|}
\hline \multicolumn{6}{|l|}{ Panel A } \\
\hline \multicolumn{3}{|l|}{ Dep Offer premium } & \multicolumn{3}{|l|}{ Dep Percentage cash payment } \\
\hline Variable & Coefficient & $p$-val & Variable & Coefficient & $p$-val \\
\hline$\overline{\text { Percentage acquired shares }}$ & 0.2588 & $\left(0.00^{a}\right)$ & $\overline{\text { Constant }}$ & 0.8905 & $\left(0.00^{\mathrm{a}}\right)$ \\
\hline Percentage cash payment & 0.1737 & $\left(0.00^{\mathrm{a})}\right.$ & Transaction value & -0.0000 & $\left(0.00^{a}\right)$ \\
\hline Imbalance offer & -0.3153 & $(0.14)$ & Same sector dummy & -0.0829 & $\left(0.07^{c}\right)$ \\
\hline Target $Q$ ratio & 0.9306 & $\left(0.04^{b}\right)$ & Domestic acquisition dummy & -0.0800 & $\left(0.09^{c}\right)$ \\
\hline Challenged deal dummy & 14.2369 & $\left(0.04^{b}\right)$ & Acquirer EBITDA(\%) & 0.0072 & $\left(0.05^{b}\right)$ \\
\hline Asymmetry \#1 & -1.2375 & $(0.41)^{\prime}$ & Offer premium & 0.0015 & $\left(0.05^{b}\right)$ \\
\hline Transaction value & -0.0001 & $(0.61)$ & Target leverage & 0.0700 & $(0.51)$ \\
\hline Same sector dummy & 2.1300 & $(0.53)$ & Challenged deal dummy & 0.1581 & $\left(0.06^{c}\right)$ \\
\hline Euro area acquirer dummy & -3.9957 & $(0.30)$ & Asymmetry \#2 & -0.0900 & $\left(0.00^{a}\right)$ \\
\hline Subsidiary target dummy & -3.6374 & $(0.44)$ & & & \\
\hline $\mathrm{N}=243$ & & & $\mathrm{~N}=243$ & & \\
\hline $\mathrm{R} 2=0.21$ & & & $\mathrm{R} 2=0.21$ & & \\
\hline \multicolumn{6}{|l|}{ Panel B } \\
\hline Dep Offer premium & & & Dep Percentage cash payment & & \\
\hline Variable & Coefficient & $p$-val & Variable & Coefficient & $p$-val \\
\hline Percentage acquired shares & 0.2597 & $\left(0.00^{\mathrm{a}}\right)$ & Constant & 0.9203 & $\left(0.00^{\mathrm{a}}\right)$ \\
\hline Percentage cash payment & 0.1460 & $\left(0.00^{\mathrm{a}}\right)$ & Transaction value & -0.0000 & $\left(0.01^{a}\right)$ \\
\hline Imbalance offer & -0.3047 & $(0.15)$ & Same sector dummy & -0.842 & $\left(0.07^{c}\right)$ \\
\hline Target $Q$ ratio & 0.7545 & $\left(0.08^{\mathrm{C}}\right)$ & Domestic acquisition dummy & -0.0976 & $\left(0.04^{b}\right)$ \\
\hline \multirow[t]{5}{*}{ Challenged deal dummy } & 14.6794 & $\left(0.03^{b}\right)$ & Acquirer EBITDA(\%) & 0.0000 & $(0.64)$ \\
\hline & & & Offer premium & 0.0014 & $\left(0.07^{\mathrm{C}}\right)$ \\
\hline & & & Target leverage & 0.0274 & $(0.79)$ \\
\hline & & & Challenged deal dummy & 0.1325 & $(0.14)$ \\
\hline & & & Asymmetry \#2 & -0.0630 & $\left(0.00^{\mathrm{a}}\right)$ \\
\hline$N=249$ & & & $\mathrm{~N}=255$ & & \\
\hline $\mathrm{R} 2=0.20$ & & & $\mathrm{R} 2=0.16$ & & \\
\hline \multicolumn{6}{|l|}{ Panel C } \\
\hline \multicolumn{3}{|c|}{ Dep Offer premium (1st step OLS) } & \multicolumn{3}{|l|}{$\begin{array}{l}\text { Dep. Percentage cash payment } \\
\text { (2nd Step Probit equation) }\end{array}$} \\
\hline Variable & $\underline{\text { Coefficient }}$ & $p$-val & $\underline{\text { Variable }}$ & $\underline{\text { Coefficient }}$ & $p$-val \\
\hline$\overline{\text { Percentage acquired shares }}$ & $\overline{0.2602}$ & $\left(0.00^{a}\right)$ & $\overline{\text { Constant }}$ & 0.5874 & $\left(0.00^{a}\right)$ \\
\hline Percentage cash payment & 0.1673 & $\left(0.00^{\mathrm{a})}\right.$ & Transaction value & -0.0000 & $\left(0.03^{a}\right)$ \\
\hline Imbalance offer & -0.3174 & $\left(0.10^{c}\right)$ & Same sector dummy & -0.0903 & $\left(0.02^{b}\right)$ \\
\hline Target $Q$ ratio & 0.6846 & $(0.24)$ & Domestic acquisition dummy & -0.0268 & $(0.50)$ \\
\hline Challenged deal dummy & 20.9402 & $\left(0.02^{b}\right)$ & Acquirer EBITDA(\%) & 0.0096 & $\left(0.00^{\mathrm{a}}\right)$ \\
\hline Asymmetry \#1 & -1.5410 & $(0.17)$ & Offer premium (fitted) & 0.0114 & $\left(0.00^{a}\right)$ \\
\hline Transaction value & -0.0002 & $\left(0.04^{b}\right)$ & Target leverage & 0.1082 & $(0.25)$ \\
\hline Same sector dummy & 2.0772 & $(0.54)$ & Challenged deal dummy & -0.1591 & $\left(0.03^{b}\right)$ \\
\hline Euro area acquirer dummy & -3.3199 & $(0.41)$ & Asymmetry \#2 & -0.0951 & $\left(0.00^{\mathrm{a}}\right)$ \\
\hline Subsidiary target dummy & -3.0755 & $(0.50)$ & & & \\
\hline $\mathrm{N}=243$ & & & $\mathrm{~N}=243$ & & \\
\hline $\mathrm{R} 2=0.20$ & & & $\mathrm{R} 2=0.33$ & & \\
\hline
\end{tabular}


Table 10 - Determinants of offer premiums and of cash percentage in hybrid payments Simultaneous linear equation estimates

(Dependants are offer premiums in percentage calculated 1 week before the announcement and percentage paid in cash in hybrid payments; linear system of two equations; Panels A, B, C see equations (3a-b), (4a-b) and (5ab)in the text; robust covariance estimate are used to adjust for heteroscedasticity; variable definitions: see Appendix; European M\&A transactions; 2000-2010; N=a: 1\% significance level; b: 5\% significance level; c: $10 \%$ significance level)

\begin{tabular}{|c|c|c|c|c|c|}
\hline \multicolumn{6}{|l|}{ Panel A } \\
\hline \multicolumn{3}{|l|}{ Dep Offer premium } & \multicolumn{3}{|c|}{ Dep Percentage cash payment } \\
\hline Variable & Coefficient & $p$-val & Variables & Coefficient & $p$-val \\
\hline Percentage acquired shares & 0.0699 & $(0.63)$ & $\overline{\text { Constant }}$ & 60.5234 & $\left(0.00^{\mathrm{a}}\right)$ \\
\hline Percentage cash payment & -0.2077 & $(0.28)$ & Same sector dummy & -2.5217 & $(0.76)$ \\
\hline Imbalance offer & -2.7326 & $(0.14)$ & Offer premium & -0.2452 & $(0.21)$ \\
\hline Target $Q$ ratio & 6.7334 & $\left(0.00^{a}\right)$ & Toehold percentage & 0.4226 & $(0.22)$ \\
\hline Challenged deal dummy & 35.4579 & $\left(0.01^{a}\right)$ & Acquirer $Q$ ratio & -0.9708 & $(0.65)$ \\
\hline Asymmetry \#1 & 3.8913 & $(0.33)$ & Target $Q$ ratio & 2.6948 & (0.57) \\
\hline Transaction value & -0.0011 & $\left(0.00^{\mathrm{a}}\right)$ & Challenged deal dummy & 0.2461 & (0.98) \\
\hline Same sector dummy & 16.2793 & $\left(0.07^{c}\right)$ & Imbalance offer & -1.5573 & (0.43) \\
\hline Euro area acquirer dummy & 9.6227 & $(0.38)$ & Asymmetry \#1 & -2.2314 & $(0.70)$ \\
\hline Subsidiary target dummy & 12.6011 & (0.33) & Acquirer EBITDA(\%) & -5.9457 & $(0.20)$ \\
\hline $\mathrm{N}=29$ & & & $\mathrm{~N}=29$ & & \\
\hline $\mathrm{R} 2=0.59$ & & & $\mathrm{R} 2=0.26$ & & \\
\hline \multicolumn{6}{|l|}{ Panel B } \\
\hline \multicolumn{3}{|l|}{ Dep Offer premium } & \multicolumn{3}{|c|}{ Dep Percentage cash payment } \\
\hline Variable & Coefficient & $\mathrm{p}$-val & Variable & $\underline{\text { Coefficient }}$ & $\mathrm{p}$-val \\
\hline Percentage acquired shares & 0.2987 & $\left(0.01^{a}\right)$ & $\overline{\text { Constant }}$ & 51.0912 & $\left(0.00^{\mathrm{a}}\right)$ \\
\hline Percentage cash payment & -0.239 & $(0.16)$ & Same sector dummy & -4.4922 & $(0.63)$ \\
\hline Imbalance offer & -0.2526 & $(0.88)$ & Offer premium & -0.3073 & $(0.15)$ \\
\hline Target $Q$ ratio & 3.2981 & $(0.15)$ & Toehold percentage & 0.0437 & $(0.89)$ \\
\hline Challenged deal dummy & 23.1298 & $\left(0.05^{b}\right)$ & Acquirer $Q$ ratio & -2.0908 & $(0.35)$ \\
\hline \multirow[t]{4}{*}{ Asymmetry \#1 } & 1.4349 & $(0.70)$ & Target $Q$ ratio & 4.8004 & (0.32) \\
\hline & & & Challenged deal dummy & 2.8683 & $(0.84)$ \\
\hline & & & Imbalance offer & -1.4388 & $(0.51)$ \\
\hline & & & Asymmetry \#1 & 3.699 & $(0.51)$ \\
\hline $\mathrm{N}=43$ & & & $\mathrm{~N}=32$ & & \\
\hline $\mathrm{R} 2=0.08$ & & & $\mathrm{R} 2=\mathrm{ns}$ & & \\
\hline \multicolumn{6}{|l|}{ Panel C } \\
\hline \multicolumn{3}{|l|}{ Dep Offer premium } & \multicolumn{3}{|c|}{ Dep Percentage cash payment } \\
\hline Variable & Coefficient & $p$-val & Variable & $\underline{\text { Coefficient }}$ & $p$-val \\
\hline Percentage acquired shares & 0.2385 & $\left(0.00^{\mathrm{a}}\right)$ & Offer premium & 0.3759 & $\left(0.03^{b}\right)$ \\
\hline Target $Q$ ratio & 5.5109 & $\left(0.01^{a}\right)$ & Same sector dummy & 18.8706 & $\left(0.06^{c}\right)$ \\
\hline Transaction value & -0.0007 & $(0.10)$ & Acquirer EBITDA(\%) & 8.6127 & $\left(0.10^{c}\right)$ \\
\hline Challenged deal dummy & 16.9877 & $(0.18)$ & Asymmetry \#1 & 8.4611 & $(0.14)$ \\
\hline $\mathrm{N}=43$ & & & $\mathrm{~N}=43$ & & \\
\hline $\mathrm{R} 2=0.16$ & & & $\mathrm{R} 2=\mathrm{ns}$ & & \\
\hline
\end{tabular}




\section{References}

Bebchuk L.A. , 1994, Efficient and Inefficient Sales of Corporate Control, Quarterly Journal of Economics, vol. 109, 957-993.

Belot F., 2010, Target Shareholder agreements, takeover premium, and acquisition likelihood, working paper, University Paris Dauphine

Betton S., Eckbo B. E., Thorburn K. , 2008, Corporate takeovers, chapter 15 in Handbook of corporate finance, volume 2, B. Eckbo ,Ed., 293-410, North Holland

Ben-Amar W., André P., 2009, Control Threat and Means of Payment: Evidence from Canadian Mergers and Acquisitions Large shareholder and form of payment in M\&A: Evidence from Canada, working paper, 2009 EFMA Symposium on Corporate governance, Milano

Berkovitch E., Narayanan M., 1990, Competition and the medium of exchange in takeovers, Review of Financial Studies, vol.3, 153-174.

Betton S., Eckbo B., 2000,'Toeholds, bid jumps, and expected payoffs in takeovers”, Review of Financial Studies, vol.13, 841-822

Burkart, M., D. Gromb, F. Panunzi, 2000, Agency Conflicts in Public and Negotiated Transfers of Corporate Control, Journal of Finance, 2000, vol. 55, 647-677.

Burkart, M., F. Panunzi , 2004,, Mandatory bids, squeeze-out, sell-out and the dynamic of tender offer process, in G. Ferrarini et al. (eds), Modern company and takeover law in Europe, 2004, 737-765, Oxford University Press, Oxford.

Carleton W., Guilkey D., Harris R., Stewart J., 1983, An empirical analysis of the role of the medium of exchange in mergers, Journal of Finance, vol. 38, 813-826

Chang S., E. Mais, 1998, Managerial motives and merge financing, The Financial Review, 2000, vol. $35 \mathrm{n}^{\circ} 4,139-152$

Cheng P., Li J., Tong W., 2008, Information Asymmetry in the Takeover Market, 2008, EFMA working paper, www.ssrn.com

Chevalier A., Redor E., 2010, The determinants of payment method choice in cross-border acquisitions”, Bankers, Markets Investors, ${ }^{\circ} 106$, june, 4-14

Chevalier A., Redor E., 2007, Les théories expliquant le choix de la méthode de paiement dans le cadre d'une opération de fusion-acquisition, Banques et Marchés, mai-juin 2007, n88, 46-54.

Cornu P., Isakov D., 2000, The deterring role of the medium of payment in takeover contests: Theory and evidence from the UK", European Financial Management, vol. 6, 423-440 
Eckbo E., 2009, Bidding strategies and takeover premiums: A review, Journal of Corporate Finance, vol. 15, 149-178

Eckbo E., Giammarino R., Heinkel R., 1990, Asymmetric information and the medium of exchange in takeovers; Theory and tests, Review of Financial Studies, vol. 3, 651-675

Faccio M., Lang L., 2002, The ultimate ownership of western European corporations, Journal of Financial Economics, vol. 65, 365-395

Faccio M., Masulis R., 2005, The choice of payment method in European mergers and acquisitions", Journal of Finance, vol. 60(3), 1345-1388

Fishman M., 1989, Preemptive bidding and the role of the medium of exchange in acquisitions, Journal of Finance, vol. 44, 41-571

Goergen M., Frecknall-Hughes J.. 2007, Mix and match facilities and loan notes in acquisitions. In: Gregoriou et al. (eds). International mergers and acquisitions activity since 1990: quantitative analysis and recent research. Quantitative Finance. Burlington, Elsevier, MA, 135-166

Goergen M., Renneboog L. , 2004, Shareholder wealth effects of European domestic and cross-border takeover bids, European Financial Management, vol. 10, no 1, 243-268

Goldman E., Qian J., 2004, Optimal toeholds in takeover contest, working paper, University of North Carolina, March

Hansen R., 1987, A theory for the choice of exchange medium in mergers and acquisitions, Journal of Business, 60, 75-95

La Bruslerie H. de, 2012, Corporate acquisition process: Is there an optimal cash-equity payment mix?, International Review of Law and Economics, vol. 32, 83-94

La Porta R., Lopez-de-Silanes F., Shleifer A., Vishny R., 1998, Law and finance, Journal of Political Economy, vol. 106, n $6,1113-1155$

Linn S.C., Switzer J.A., 2001, Are cash acquisitions associated with better post combination operating performance than stock acquisitions? Journal of Banking and Finance, vol. 25, 1113-1138.

Martin K.J., 1996, The method of payment in corporate acquisitions, Investment Opportunities, and Management Ownership, Journal of Finance, vol. 51, no 4, 1227 1246.

Martynova M., Renneboog L., 2006, Mergers and acquisitions in Europe: the fifth takeover wave. In: Renneboog, L. (Ed.), Advances in Corporate Finance and Asset Pricing, Elsevier, Amsterdam, 15-75 
Martynova M., Renneboog L., 2009, What determines the financing decision in corporate takeovers: Cost of capital, agency problems, or the means of payment, Journal of Corporate Finance, vol. 15, 290-315

Martynova M., Renneboog L., 2011, The Performance of the European Market for Corporate Control: Evidence from the Fifth Takeover Wave, European Financial Management, $17,208-259$

Moeller S., Schlingemann F., Stulz R., 2005, Wealth Destruction on a Massive Scale? A Study of Acquiring-Firm Returns in the Recent Merger Wave, Journal of Finance, Vol. 60, n 2, 757-782

Myers S., Majluf N., 1984, Corporate financing and investment decisions when firms have information that investors do not have, Journal of Financial Economics, 1984, vol. 13, $187-221$

Officer M., 2003, “Termination fees in mergers and acquisitions”, Journal of Financial Economics, vol. 69, 431-467

Song M., Walking R. , 1993, The Impact of Managerial Ownership on Acquisition Attempts and Target Shareholder Wealth , Journal of Financial and Quantitative Analysis, vol.28, 439-457

Shleifer A., Vishny R., 2003, Stock market driven acquisitions, Journal of Financial Economics, vol. 70, 295-311

Stulz R., 1988, Managerial control of voting rights: Financing policies and the market for corporate control, Journal of Financial economics, vol.20, 25-54

Stulz R., Walking R., Song M., 1990, The distribution of target ownership and the division of gains in successful takeovers, Journal of Finance, vol. 45, 817-83

Sundarsanam S., 1996, Target shareholder, takeovers and target valuation, Journal of Business, Finance and Accounting, vol.23, 295-314

Travlos N., 1987, Corporate takeover bids, method of payment, and acquiring firm's stock returns, Journal of Finance, vol. 42, 943-963

Volpin P., 2002, Governance with poor investor protection: evidence from top executive turnover in Italy" Journal of Financial Economics, vol. 64, 61-90 
Appendix - Definition of variables

(LTM: Last Twelve Months: financial information is taken from the last reports prior the announcement; source: Thomson Financial and treatments)

\begin{tabular}{|c|c|c|}
\hline Variable name & Variable acronym & Description \\
\hline Acquirer cash holding & ACQ_CASH_HLDG & $\begin{array}{l}\text { Acquirer cash and receivables as of the previous } \\
\text { financial report (\$mil) }\end{array}$ \\
\hline Acquirer EBITDA & ACQ_EBITDA & Acquirer EBITDA at last financial report (\$mil) \\
\hline Acquirer debt leverage & ACQ_LEV & $\begin{array}{l}\text { Calculated using the ratio of ACQ_NET_DEBT } \\
\text { divided by ACQ_NET_DEBT plus } \\
\text { ACQ_NET_ASS }\end{array}$ \\
\hline Acquirer market value & ACQ_MKT_VAL_4W & $\begin{array}{l}\text { Acquirer market value of equity } 4 \text { weeks prior to } \\
\text { announcement ( } \$ \text { mil) }\end{array}$ \\
\hline Acquirer net assets & ACQ_NET_ASS & $\begin{array}{l}\text { Acquirer net assets : Total asset at last financial } \\
\text { report minus total liabilities (\$mil) }\end{array}$ \\
\hline Acquirer net debt & ACQ_NET_DEBT & $\begin{array}{l}\text { Acquirer Net Debt: Calculated by adding the } \\
\text { acquirer's straight debt, short-term debt, and } \\
\text { preferred equity and subtracting cash and } \\
\text { marketable securities as of the date of the most } \\
\text { recent financial information prior to the } \\
\text { announcement of the transaction (\$mil). }\end{array}$ \\
\hline Acquirer cash holding & ACQ_PC_CASH & $\begin{array}{l}\text { Acquirer ratio of cash holding, } \\
\text { ACQ_CASH_HLDG, divided by transaction } \\
\text { value, TRANS_VAL }\end{array}$ \\
\hline $\begin{array}{l}\text { Acquirer percent } \\
\text { EBITDA }\end{array}$ & ACQ_PC_EBITDA & $\begin{array}{l}\text { Acquirer ratio of EBITDA (ACQ_EBITDA) } \\
\text { divided by transaction value, TRANS_VAL. } \\
\text { Calculated only if ACQ_EBITDA is positive. }\end{array}$ \\
\hline Acquirer $\mathrm{Q}$ ratio & ACQ_Q & $\begin{array}{l}\text { ACQ_MKT_VAL_4W divided by } \\
\text { ACQ_NET_ASS. Equity market to book is used } \\
\text { as a proxy of the Tobin's Q. }\end{array}$ \\
\hline Asymmetry \#1 & ASYMMETRY1 & $\begin{array}{l}\text { Ratio of relative net assets: TARG_NET_ASS } \\
\text { divided by ACQ_NET_ASS. Not calculated for } \\
\text { negative values of TARG_NET_ASS }\end{array}$ \\
\hline Asymmetry \#2 & ASYMMETRY2 & $\begin{array}{l}\text { Ratio of the transaction value of the target } \\
\text { compared with the book value of the acquirer: } \\
\text { TRANS_VAL divided by ACQ_NET_ASS. Not } \\
\text { calculated for negative values of } \\
\text { TARG_NET_ASS }\end{array}$ \\
\hline Imbalanced offer & DISEQ & $\begin{array}{l}\text { Disequilibrium in the transaction setting: } \\
\text { difference between the percentage of shares } \\
\text { sought by the acquirer and the percentage of } \\
\text { shares acquired. }\end{array}$ \\
\hline $\begin{array}{l}\text { Domestic acquisition } \\
\text { dummy }\end{array}$ & DOMESTIC_ACQ & $\begin{array}{l}\text { Dummy if the target and the acquirer are } \\
\text { incorporated in the same country }\end{array}$ \\
\hline $\begin{array}{l}\text { Pure cash payment } \\
\text { dummy }\end{array}$ & DUM_CASH & Dummy for full cash payment \\
\hline $\begin{array}{l}\text { Challenged deal } \\
\text { dummy }\end{array}$ & $\begin{array}{l}\text { DUM_CHALLGED_DEA } \\
\text { L }\end{array}$ & $\begin{array}{l}\text { Dummy challenged deal where a third party } \\
\text { launched an offer }\end{array}$ \\
\hline $\begin{array}{l}\text { Euro area acquirer } \\
\text { dummy }\end{array}$ & DUM_EU_ZONE & $\begin{array}{l}\text { Dummy if acquirer is incorporated in the EU } \\
\text { (limited to } 7 \text { countries) }\end{array}$ \\
\hline $\begin{array}{l}\text { Mixed payment } \\
\text { dummy }\end{array}$ & DUM_HYBRID & $\begin{array}{l}\text { Dummy for mixed cash-share payment } \\
\text { transactions }\end{array}$ \\
\hline $\begin{array}{l}\text { Pure share payment } \\
\text { dummy }\end{array}$ & DUM_SH & Dummy for full share payment \\
\hline $\begin{array}{l}\text { Subsidiary target } \\
\text { dummy }\end{array}$ & DUM_SUBSIDIARY & Dummy is target is a subsidiary \\
\hline Toehold dummy & DUM_TOE & $\begin{array}{l}\text { Dummy for toehold shares of the target held } \\
\text { before the transaction. See TOEHOLD. }\end{array}$ \\
\hline
\end{tabular}




\begin{tabular}{|c|c|c|}
\hline $\mathrm{ROA}$ & EBIT_ROA & $\begin{array}{l}\text { Target EBIT divided by Total Assets for the last } \\
12 \text { months ending on the date of the most current } \\
\text { financial information }\end{array}$ \\
\hline Enterprise value & ENT_VAL & $\begin{array}{l}\text { Enterprise Value of the target calculated by } \\
\text { multiplying the number of actual target shares } \\
\text { outstanding (from the most recent balance sheet } \\
\text { released prior to the announcement) by the offer } \\
\text { price and then by adding the cost to acquire } \\
\text { convertible securities, plus short-term debt, } \\
\text { straight debt, and preferred equity minus cash and } \\
\text { marketable securities, stated in millions. This data } \\
\text { item is for the enterprise value of } 100 \% \text { of the } \\
\text { company based on the offering price, regardless } \\
\text { of how much was actually acquired in the } \\
\text { transaction. }\end{array}$ \\
\hline Equity value & EQ_VAL & $\begin{array}{l}\text { Equity Value of the target calculated by } \\
\text { multiplying the actual number of target shares } \\
\text { outstanding from its most recent balance sheet by } \\
\text { the offer price per share plus the cost to acquire } \\
\text { convertible securities, stated in millions. This data } \\
\text { item is for the equity value of } 100 \% \text { of the } \\
\text { company based on the offering price. }\end{array}$ \\
\hline Friendly attitude & FRIEN_ATTITUD & $\begin{array}{l}\text { Attitude of the board of the target company. } \\
\text { Dummy variable (0: not friendly, 1:yes) }\end{array}$ \\
\hline Offer premium & OFFER_PREMIUM_4W & $\begin{array}{l}\text { Offer price divided by target stock price } 4 \text { weeks } \\
\text { prior minus } 1(\%)\end{array}$ \\
\hline $\begin{array}{l}\text { Acquirer percentage of } \\
\text { issued shares }\end{array}$ & PERC_ACQ_SH_ISSU & $\begin{array}{l}\text { Percentage of acquirer's shares issued: Number of } \\
\text { common shares issued in the transaction divided } \\
\text { by total number of acquirer's shares. }\end{array}$ \\
\hline $\begin{array}{l}\text { Percentage of cash } \\
\text { payment }\end{array}$ & PERC_CASH & $\begin{array}{l}\text { Percentage of cash and assimilated (debt) paid in } \\
\text { the transaction }\end{array}$ \\
\hline $\begin{array}{l}\text { Percentage target } \\
\text { owned }\end{array}$ & PERC_OWN_AFTER & $\begin{array}{l}\text { Percentage of target shares owned after } \\
\text { transaction }\end{array}$ \\
\hline $\begin{array}{l}\text { Percentage of acquired } \\
\text { target shares }\end{array}$ & PERC_SH_ACQ & Percentage of target shares acquired in transaction \\
\hline Percentage sought & PERC_SOUGHT & $\begin{array}{l}\text { Percentage of target shares sought by acquirer in } \\
\text { the transaction }\end{array}$ \\
\hline Same sector dummy & SAME_SECTOR & $\begin{array}{l}\text { Dummy for same industry codes between target } \\
\text { and acquirer. Thomson mid sector codes are used. }\end{array}$ \\
\hline Target debt leverage & TARG_LEV & $\begin{array}{l}\text { Ratio of } 1 \text { minus EQ_VAL divided by } \\
\text { ENT_VAL. }\end{array}$ \\
\hline Target net assets & TARG_NET_ASS & $\begin{array}{l}\text { Target Net Assets: Total assets minus total } \\
\text { liabilities on the date of most recent financial } \\
\text { information ( } \$ \mathrm{mil})\end{array}$ \\
\hline Target cash holding & TARG_PC_CASH & $\begin{array}{l}\text { Ratio of target cash and receivables, } \\
\text { TARG_CASH_HLDG, divided by transaction } \\
\text { value, TRANS_VAL. }\end{array}$ \\
\hline Target $\mathrm{Q}$ ratio & TARG_Q & $\begin{array}{l}\text { Ratio of Enterprise Value to Target } \\
\text { Capitalization: Enterprise value is calculated by } \\
\text { multiplying the number of actual target shares } \\
\text { outstanding by the offer price and then by adding } \\
\text { the cost to acquire convertible securities, plus } \\
\text { short-term debt, straight debt, and preferred } \\
\text { equity minus cash and marketable securities. } \\
\text { Capitalization is defined at Short-Term Debt + } \\
\text { Long-Term Debt + Shareholder's Equity as of the } \\
\text { date of the most current financial information } \\
\text { prior to the announcement. }\end{array}$ \\
\hline Toehold percentage & TOEHOLD & $\begin{array}{l}\text { Percentage of share of the target held before the } \\
\text { transaction. Calculated using the difference }\end{array}$ \\
\hline
\end{tabular}


between PERC_OWN_AFTER minus

PERC_SH_ACQD

Transaction value

TRANS_VAL

Value of Transaction (\$ mil): Total value of consideration paid by the acquirer, excluding fees and expenses. 